\title{
The Effects of Recombinant Synucleins and Insulin-like Growth Factor 1 on Cancer Cell Migration
}

\author{
Wookjin Shin and Jongsun Kim* \\ Department of Microbiology and Brain Korea 21 Projects For Medical Science, Institute for Immunology and \\ Immunological Diseases, Yonsei University College of Medicine, Seoul, Korea
}

The synuclein family consists of three distinct genes, $\alpha$-synuclein, $\beta$-synuclein, and $\gamma$-synuclein. The $\alpha$-synuclein and $\beta$-synuclein are predominately expressed in brain and especially $\alpha$-synuclein is related with Parkinson's disease, Alzheimer's disease, and dementia with Lewy bodies. The $\gamma$-synuclein was first identified as breast cancer specific gene 1. It is expressed in the peripheral nervous system and also detected in breast and ovarian cancers. The $\gamma$-synuclein is also known to mediate metastasis of breast and ovarian cancer cells. Insulin-like growth factor 1 (IGF-I) is one of the growth factors that plays an important role in cell proliferation and migration in cancer cells, as well as in normal cells. In this study, we investigated the migrations of SKOV-3, MDAMB-231, and HeLa cells by the recombinant synuclein proteins ( $\alpha$-, $\beta$-, and $\gamma$-synucleins) and IGF-I and the molecular mechanism. Furthermore, we investigated the membrane ruffle formation of SKOV-3 cells by recombinant synuclein proteins and IGF-I. As a result, synucleins and IGF-I were found to induce cancer cell migrations. Simultaneous synucleins and IGF-I treatment on the cancer cells induced more migrations than the individual synuclein or IGF-I treatments. The synucleins or IGF-I treatments increased the expressions of membrane-type1 matrix metalloproteinase (MT1-MMP) and cluster of differentiation 44 (CD44). Moreover, simultaneous synucleins and IGF-I treatments further increased the expressions of MT1-MMP and CD44. The synucleins and IGF-I promoted the conformational change of actin filaments, and then this led to the membrane ruffle formation.

Key Words: $\alpha$-, $\beta$-, $\gamma$-synuclein, IGF-I, Migration, MT1-MMP, CD44, Membrane ruffling

\section{서 론}

Synuclein family는 $\alpha-, \beta-, \gamma$-synuclein으로 이루어져 있다. $\alpha-, \beta-, \gamma$-synuclein의 실제 분자량은 각각 $14.4 \mathrm{kDa}, 14.2$ $\mathrm{kDa}, 13.3 \mathrm{kDa}$ 정도 되는 작은 단백질이다. 그러나 젤 상 에서의 분자량은 $18 \sim 20 \mathrm{kDa}$ 정도 되는 것으로 나타나는 데, 이는 synuclein의 구조적 특성 및 전사 후 조절작용에

Received: May 22, 2012/ Revised: June 4, 2012

Accepted: June 5, 2012

* Corresponding author: Jongsun Kim, PhD. Department of Microbiology and Brain Korea 21 Projects For Medical Science, Institute for Immunology and Immunological Diseases, Yonsei University College of Medicine, 134 Shinchon-dong, Seodaemoon-gu, Seoul 120-752, Korea. Phone: +82-2-2228-1814, Fax: +82-2-392-7088

e-mail: jkim63@yuhs.ac

** This study was supported by a basic research grant (R01-2007-00020089-0) of the KOSEF.
의한 것이다 (1). $\alpha$-synuclein은 펼쳐진 구조를 하고 있어 단백질-단백질 상호작용에 유리한 구조를 하고 있는 것 으로 추측하고 있다 (2). $\alpha-, \beta$-synuclein은 주로 뇌에 많 이 발현하는데, 특히 대뇌 신피질, 해마, 선상체, 시상, 소뇌에 존재한다. 또한 뉴런의 시냅스 후 말단에 많이 분포하고 있다 $(3,4)$. 특히 $\alpha$-synuclein은 Parkinson 씨병, Alzheimer 병, dementia with Lewy bodies, multiple system atrophy 등과 관련 있는 것으로 알려져 있다 (5). $\alpha-, \beta-$ synuclein의 정상적인 기능은 잘 알려져 있지 않으나, 시 냅스 후 말단의 membrane-associated processes에 관련되 어 기능을 수행하고 있다는 몇 가지 보고가 있다 (6 10). $\gamma$-synuclein이 처음 종양과 연관성이 있을 것이라는 것 은, $\gamma$-synuclein이 발달된 침투성 유방암에 breast cancer specific gene 1 (BCSG1)의 이름으로 과 발현되어 있다는 보고가 있은 직후이다 (11). $\gamma$-synuclein은 말초신경계인 
제 1 차 감각신경세포, 교감신경세포, 운동신경세포에 발 현되어 있고 (11), 또한 뇌 (12), 난소암 (13), 후각 상피 에도 발견된다 (14). $\gamma$-synuclein의 정상적인 기능은 $\alpha$-, $\beta$-synuclein과 마찬가지로 잘 알려져 있지 않고, $\alpha-, \beta$ synuclein과 아미노 말단 부분에서 가장 높은 유사성을 보인다 (13). 비정상적인 $\gamma$-synuclein의 과 발현은 유방암 과 난소암 말기에서 많이 발견되고 그뿐만 아니라 간암, 위암, 췌장암에서도 발견된다 (11, 15 18). $\gamma$-synuclein은 아마도 다기능적인 단백질로써 발현이 증가되면 유방암 의 침투와 전이를 촉진시킨다는 보고가 있다 (19).

분자적인 측면에서 암 전이 과정의 기작은 다양하다. 그 중에서 세포-세포, 세포-매트릭스 부착, 단백질 분해 효소에 의한 extracellular matrix (ECM)의 분해, 새로운 곳 에서 증식의 시작과 유지가 중요하다 (20). 암 전이는 매 우 비효율적인 과정으로 보이는데, 이는 적은 수의 암 세 포가 일차 종양으로부터 탈출하기 때문이다. 암 전이 과 정은 불연속적인 단계의 연속적인 과정으로 정의 내려진 다 (21). 이러한 단계는 일차 종양으로부터의 탈출, 림프 관이나 혈관으로의 침투, 혈관을 따라 이동하면서 생존, 새로운 곳에서 조직으로 침투하여 생존하는 과정이 있다. 암 세포가 전이되기 위해서는 이러한 단계를 모두 극복 해야 된다. 종양세포 표면에는 생존, 증식, 면역탈출, 전 이에 관여하는 여러 가지 단백질이 존재한다 (22). 전이 와 관련된 표면 단백질 중에 전이를 촉진하는 것으로 잘 알려진 물질은 matrix metalloproteinase (MMP)이다. MMP 는 지난 40년이 넘도록 종양에 관여하는 것으로 알려져 있고 $\mathrm{ECM}$ 을 분해하여 종양세포의 전이를 일으킨다는 보 고가 있다 (23). MMP 중에서도 MMP2와 MMP9는 MT1$\mathrm{MMP}$ 와 $\mathrm{CD} 44$ 와 상호작용을 통해 전이를 증가시킨다는 보고가 있다 (24).

$\gamma$-synuclein은 유방암 세포뿐만 아니라 여러 종류의 암 세포에 많이 존재한다는 것이 알려져 있다 (18). 최근에는 $\gamma$-synuclein 뿐만 아니라, $\alpha$-, $\beta$-synuclein 또한 뇌에서 여러 신경세포의 종양에 많이 관여한다는 연구 결과가 있다 $(25,26)$. 암 세포의 전이는 여러 요인에 의해서 촉진 및 억제되고 있다고 알려지고 있다 (27). $\gamma$-synuclein을 형 질주입한 유방암 세포주인 MDAMB-435 세포의 전이 및 침투를 확인한 실험 결과, $\gamma$-synuclein을 형질주입한 MDAMB-435 세포에서 전이 및 침투능이 증가하였다 (19). 소신경교세포주인 BV-2 세포에 $\alpha$-synuclein의 야생 형과 돌연변이형을 형질주입하여 전이를 확인한 실험 결
과, $\alpha$-synuclein의 야생형과 돌연변이형을 형질주입한 BV-2 세포에서 운동성이 증가하였다 (28). 이렇게 $\alpha$-synuclein 의 야생형과 돌연변이형에 의해 전이가 촉진되는 것이 $\mathrm{MT1}-\mathrm{MMP}$ 와 $\mathrm{CD} 44$ 의 증가에 의한 것이라는 가설을 통 하여 두 가지 유전자의 mRNA와 단백질 수준에서의 발 현 정도를 살펴보았고, 그 결과 MT1-MMP와 CD44의 mRNA와 단백질 모두에서 발현이 증가하였다 (28). 또 다른 연구로는 난소암 세포주인 A2780과 OVCAR5에 $\gamma$-synuclein을 형질주입하거나 $\gamma$-synuclein의 siRNA를 형 질주입하여 종양세포의 전이와 침투능을 확인하였다. 그 결과, $\gamma$-synuclein을 발현하는 A2780과 OVCAR5 세포는 $\gamma$-synuclein을 발현하지 않는 세포보다 운동성이 높다는 결과를 보여주고 있다 (29).

IGF-I은 세포의 증식과 전이에 중요한 성장 인자다. IGF-I은 내분비물, 근거리분비물, 자가분비물로써 간에서 가장 중요한 역할을 할 뿐만 아니라 근육, 뼈, 연골, 신 장, 뇌, 피부, 폐에서도 작용한다 $(30,31)$. IGF-I은 표적 조직에서의 특정 IGF 수용체에 의해 조절된다. IGF-I이 IGF-I 수용체에 결합되면 IGF-I 수용체가 활성화되어 phosphatidylinositol 3-kinase (PI3K)와 mitogen-activated protein kinase (MAPK) 기전에 의해 세포 성장, 생존, 증식 에 중요한 역할을 한다 (32). IGF-I은 세포의 성장에 있어 없어서는 안될 중요한 요소이나, IGF-I의 신호기전으로 암 세포 증식에 중요한 역할을 한다. 최근 연구에 의하면 $\mathrm{IGF}$ 의 증가로 대장암, 유방암, 폐암, 전립선암의 발병률 을 증가시킨다는 보고가 있다 (33 36). 실제 유방암 환자 에서 체내 IGF-I의 양이 상당히 증가되어 있고, IGF-I의 발현량 또한 증가되어 있다는 보고가 있다 (37). IGF-I 수 용체에 의한 종양의 성장, 혈관생성, 전이에 의해 암의 진행이 촉진되고, IGF-I 수용체를 막으면 종양 형성과 암 전이가 억제된다 (38 40). 최근에는 여러 종양세포에서 IGF-I이 $\gamma$-synuclein의 발현을 증가시키고, $\gamma$-synuclein과 IGF-I 수용체의 상호조절 과정에 의해 IGF-I 신호전달이 촉진되며 이로 인해 종양세포의 증식과 전이가 촉진된다 고 밝혀졌다 (41).

$\gamma$-synuclein이 과 발현되어 있는 유방암 세포에서 증식 과 전이가 촉진된다는 보고가 있고 (20), $\alpha$-synuclein이 과 발현되어 있는 소신경교세포에서 전이가 촉진된다는 보고가 있다 (28). 또한 여러 종양세포에서 $\gamma$-synuclein과 IGF-I의 상호조절 과정에 의해 IGF-I 신호전달이 촉진됨 으로써 종양세포의 증식과 전이가 촉진된다고 밝혀졌다 
(41). 이러한 연구결과들을 바탕으로 본 연구에서는 $\gamma$ synuclein 뿐만 아니라 유사성이 높은 $\alpha$-, $\beta$-synuclein이 종양세포의 운동성에 미치는 영향을 알아보고자 실험을 수행하였고, $\gamma$-synuclein과 상호작용을 하고 종양세포의 증식과 전이에 관여하는 IGF-I을 동시에 처리했을 때 종 양세포의 운동성에 미치는 영향이 배가되는지를 알아보 았다. 또한 재조합 synuclein 단백질과 IGF-I이 종양세포 의 운동성에 미치는 영향의 분자 기전을 알아보고자 하 는 연구도 수행하였다.

\section{재료 및 방법}

\section{실험재료}

실험에 사용한 세포주는 난소암 세포주인 SKOV-3 세 포, 유방암 세포주인 MDAMB-231 세포, 자궁경부암 상 피세포주인 $\mathrm{HeLa}$ 세포를 사용하였다. 배지는 McCoy's 5A (Gibco, USA), Eagle's minimum essential medium (MEM, Gibco, USA), Dulbecco's modified Eagle's medium (DMEM, Gibco, USA)을 사용하였다. 재조합 synuclein 단백질을 크로마토그래피법으로 정제하기 위하여 DEAE Sepharose (GE Healthcare, USA)와 Sephacryl ${ }^{\mathrm{TM}}$ S-200 (GE Healthcare, USA)을 사용하였다. 실험에 사용한 주요물질인 IGF-I (ATGen, Korea)은 구입하여 사용하였다. Detoxi-Gel Endotoxin Removing Column (Termo Scientific, USA)을 사용하여 단백질에 포함된 내독소를 제거하였고, Limulus Amebocyte Lysate (LAL) QCL-1000 (Lonza, USA)을 사용하여 내독소 의 양을 측정하였다. Fluorescence activated cell sorting (FACS) 분석법으로 MT1-MMP와 CD44의 발현을 확인하 기 위해서 anti-MMP-14/MT1-MMP (R\&D Systems, USA)와 anti-CD44 (BD Pharmingen, USA) 항체를 사용하였다. 세 포의 F-actin을 염색하는 rhodamine phalloidine (Molecular Probe, USA)을 사용하여 confocal microscopy를 수행하여 세포의 membrane ruffling 현상을 확인하였다.

\section{세포 배양}

SKOV-3 세포는 $10 \%$ fetal bovine serum (FBS, Gibco, USA)가 포함된 McCoy's 5A 배지를, MDAMB-231 세포 는 $10 \% \mathrm{FBS}$ 가 포함된 $\mathrm{MEM}$ 배지를, $\mathrm{HeLa}$ 세포는 $10 \%$ $\mathrm{FBS}$ 가 포함된 DMEM 배지를 사용하여 배양하였다. 각 각의 배지에는 $1 \%$ penicillin-streptomycin (Gibco, USA)이 포함되었으며, 세포는 $5 \%$ 의 $\mathrm{CO}_{2}$ 가 있는 $37^{\circ} \mathrm{C}$ 에서 배양
하였다.

\section{재조합 synuclein 단백질의 정제}

재조합 synuclein DNA로 형질전환된 E. coli를 얻기 위 해 E. coli $\mathrm{BL} 21$ 적격세포(RBC Bioscience, USA)에 $\alpha-, \beta-$, $\gamma$-synuclein DNA plasmid를 첨가한 후 10 분간 $4^{\circ} \mathrm{C}$ 처리하 였다. 형질전환된 대장균을 $\mathrm{LB}$ plate에 도말하여 $37^{\circ} \mathrm{C}$ 에 서 overnight하였다. Colony가 형성된 후 하나의 colony 를 ampicillin (100 $\mu \mathrm{g} / \mathrm{ml}$, Sigma, USA)이 포함된 LB 배지 에 접종하여 $37^{\circ} \mathrm{C}$ 에서 overnight하여 대량 배양하였다. 원심분리를 통하여 박테리아를 모아 초음파파쇄기(Sonics \& Materials, USA)를 이용하여 세포를 용해시키고, 원심분 리하여 상층액을 분리하고 15 분간 중탕으로 열처리하였 다. Synuclein은 수용성 단백질로 약한 양전하를 띠고 있 으므로 다시 원심분리하고 상층액을 DEAE Sepharose를 사용한 이온교환 크로마토그래피 분리법을 수행하였다. Synuclein의 $\mathrm{pI}$ 값은 4.8 이므로 효율적인 정제를 위해 완 충용액은 $\mathrm{pH}$ 6.0의 MES [2-(N-morpholino) ethanesulfonic acid]를 사용하였다. 크기에 의한 분리를 다시 하기 위해 서 Sephacryl ${ }^{\mathrm{TM}}$ S-200을 사용하여 gel filtration 크로마토그 래피 분리법을 수행하였다. Gel filtration 크로마토그래피 분리법을 수행하기 위해 phosphate buffered saline (PBS, $\mathrm{pH}$ 7.4)을 완충용액으로 사용하였다.

\section{단백질 정량}

Bicinchoninic acid (BCA) Protein Assay kit (Pierce Biotechnology, USA)을 사용하여 재조합 synuclein 단백질 과 IGF-I의 농도를 정량하여 실험에 사용하였다. 표준물 질인 $1 \mathrm{mg} / \mathrm{ml}$ 의 bovine serum albumin (BSA, Sigma, USA) $20 \mu 1$ 와 재조합 synuclein 단백질과 IGF-I $20 \mu \mathrm{l}$ 에 BCA 수 용액 $200 \mu \mathrm{l}$ 넣어주고 상온에서 30 분간 반응시켰다. 반응 이 끝난 후 ELISA reader로 $450 \mathrm{~nm}$ 파장에서 흡광도를 측 정하였다. 표준물질과 재조합 synuclein 단백질과 IGF-I의 흡광도를 비교하여 정확한 농도를 측정하였다.

Sodium dodecyl sulfate polyacrylamide gel electrophoresis (SDS-PAGE)

$2 \mathrm{mg} / \mathrm{ml}$ 농도의 정제된 단백질들을 SDS-PAGE를 통 해 분석하였다. SDS-PAGE에 사용될 시료를 만들기 위하 여 단백질 $20 \mu \mathrm{l}$ 에 loading buffer $5 \mu \mathrm{l}$ 를 넣고 5 분간 중탕 하여 열처리하였다. $30 \%$ acrylamide $/ 0.8 \%$ bisacrylamid, Tris 
(pH 8.8)/SDS ( $\mathrm{pH} 6.8$ ), 10\% ammonium persulfate (APS), tetramethylethylenediamine (TEMED)를 이용해 $15 \%$ 의 SDSPAGE gel을 만든 후 시료를 $15 \mu$ 씩 loading 하였다. $100 \mathrm{~V}$ 의 전압으로 전기영동을 하여 분자량에 따라 단백질을 분리하였다. 전기영동이 끝난 후 Coomassie brilliant blue 염색법으로 분리된 단백질을 염색하여 분석하였다.

\section{내독소 제거}

정제한 재조합 synuclein 단백질을 Detoxi-Gel endotoxin removing column을 이용하여 내독소를 제거하였다. 우선 $5 \mathrm{ml}$ 의 $1 \%$ sodium deoxycholate (Sigma, USA)을 column 안으로 흘려주어 polymyxin B bead를 재생시킨 후, $5 \mathrm{ml}$ 의 $1 \times$ PBS로 sodium deoxycholate를 제거하였다. 재조합 synuclein 단백질을 column에 넣고 column을 막아서 멈 추게 한 후, 재조합 synuclein 단백질과 polymyxin B bead 를 1시간 동안 반응시켰다. Column에 $\mathrm{PBS}$ 를 흘려주어 내독소가 제거된 재조합 단백질을 얻은 후 LAL test로 내독소의 양을 확인하였다.

\section{LAL test}

LAL QCL-1000를 사용하여 내독소 제거 전 후의 재조 합 synuclein 단백질에 함유된 내독소 양을 측정하였다. 우선 blank와 내독소 표준 농도, 단백질 $50 \mu \mathrm{l}$ 를 96-well microplate에 넣어주었다. $50 \mu \mathrm{l}$ 의 $\mathrm{LAL}$ 를 넣고 $37^{\circ} \mathrm{C}$ 배양 기에 10 분간 넣어주었다. $100 \mu \mathrm{l}$ 의 chromogenic substrate solution을 넣고 $37^{\circ} \mathrm{C}$ 배양기에서 6 분간 반응시켰다. 반응 중지액인 25\% acetic acid (v/v) $100 \mu \mathrm{l}$ 를 넣은 후, $405 \mathrm{~nm}$ 에서 흡광도를 측정하여 단백질에 포함된 내독소 양을 정량하였다.

\section{Wound healing assay}

24-well plate에 단일 세포층의 SKOV-3, MDAMB-231, 및 $\mathrm{HeLa}$ 세포가 $90 \%$ 이상 confluent하도록 접종하였다. MDAMB-231 세포는 $4 \times 10^{5} / \mathrm{well}, \mathrm{HeLa}$ 세포는 $5 \times$ $10^{5} /$ well, SKOV-3 세포는 $5 \times 10^{4} /$ well 씩 접종하여 세포 를 plate 바닥에 부착시켰다. Pipette tip를 이용하여 plate 바닥을 긁어 세포가 부착되지 않은 부분을 만들었다. $\mathrm{PBS}$ 로 2 번 헹궈 떨어져 나간 세포들을 제거하였다. 그 후 $1 \% \mathrm{FBS}$ 가 포함된 배지에 $100 \mathrm{nM}$ 또는 $500 \mathrm{nM}$ 의 재 조합 synuclein 단백질만 처리하거나, $5 \mathrm{ng} / \mathrm{ml}$ 의 IGF-I만 처리하거나, $500 \mathrm{nM}$ 의 재조합 synuclein 단백질과 $5 \mathrm{ng} / \mathrm{ml}$
의 IGF-I을 같이 처리하였다. 상처가 생긴 후 0 시간과 24시간에 같은 위치를 도립현미경(Olympus, Japan)으로 $\times 40$ 배율로 촬영하였다. 실험을 3 번 반복하여 24 시간 동안 줄어든 면적을 ImageJ (National Institutes of Health, $\mathrm{USA}$ 로 측정하여 평균값을 계산하였다.

\section{FACS}

SKOV-3, MDAMB-231, HeLa 세포에 $500 \mathrm{nM}$ 의 재조합 synuclein 단백질만 처리하거나, $5 \mathrm{ng} / \mathrm{ml}$ 의 IGF-I만 처리 하거나, $500 \mathrm{nM}$ 의 재조합 synuclein 단백질과 $5 \mathrm{ng} / \mathrm{ml}$ 의 IGF-I을 같이 처리하여 24 시간 동안 $37^{\circ} \mathrm{C}, 5 \% \mathrm{CO}_{2}$ 배양 기에서 배양하였다. 세포 수는 $5 \times 10^{5}$ 으로 동일하게 하 고 항체는 anti-MMP-14/MT1-MMP와 anti-CD44 항체를 사용하여 $-4{ }^{\circ} \mathrm{C}$ 에서 30 분간 세포와 반응시켜 세포에 형광 을 표지되도록 하였다. 결합되지 않은 항체는 $2 \% \mathrm{FBS}$ 가 포함된 $\mathrm{PBS}$ 로 원심분리하여 제거하였다. LSR II (BD biosciences, USA)를 이용하여 각각의 세포주에서 MT1$\mathrm{MMP}$ 와 $\mathrm{CD} 44$ 의 발현을 확인하였다.

Confocal microscopy

Lab Tek 4 chamber (Nunc, USA)에 chamber 당 $1 \times$ $10^{4}$ 개의 SKOV-3 세포를 접종하여 $500 \mathrm{nM}$ 의 재조합 synuclein 단백질만 처리하거나, $5 \mathrm{ng} / \mathrm{ml}$ 의 IGF-I만 처리 하거나, $500 \mathrm{nM}$ 의 재조합 synuclein 단백질과 $5 \mathrm{ng} / \mathrm{ml}$ 의 IGF-I을 같이 처리하여 $37^{\circ} \mathrm{C}, 5 \% \mathrm{CO}_{2}$ 배양기에서 24시 간 동안 배양하였다. 배양 후 $3.7 \%$ formaldehyde로 세포 를 고정하였고, $0.1 \%$ Triton X-100을 사용하여 세포 내부 로의 투과성을 높였다. $1 \% \mathrm{BSA}$ 를 세포에 1 시간 동안 처 리하여 비특이적 결합을 방지하였다. 세포 내 F-actin에 형광을 표지하기 위해 10 unit의 rhodamine phalloidine을 세포에 처리하여 $4^{\circ} \mathrm{C}$ 에서 overnight하였다. 4',6-diamidino2-phenylindole (DAPI)가 포함된 mounting solution을 사용 하여 세포 핵에 형광을 표지하였다. Confocal microscope (OLYMPUS FV-1000, Japan)로 600 배율로 촬영하였다.

통계 처리

Wound healing assay의 결과 분석을 위하여 3 번 $(\mathrm{n}=3)$ 의 독립된 실험으로 얻은 평균값 \pm 표준편차 값으로 통계 처리하였다. PRISM Software (GraphPad Software Inc., USA)를 이용하여, One-way ANOVA와 Dunnett's multiple comparison test로 $p$ 값이 0.05 보다 작은 경우는 *로, $p$ 값 


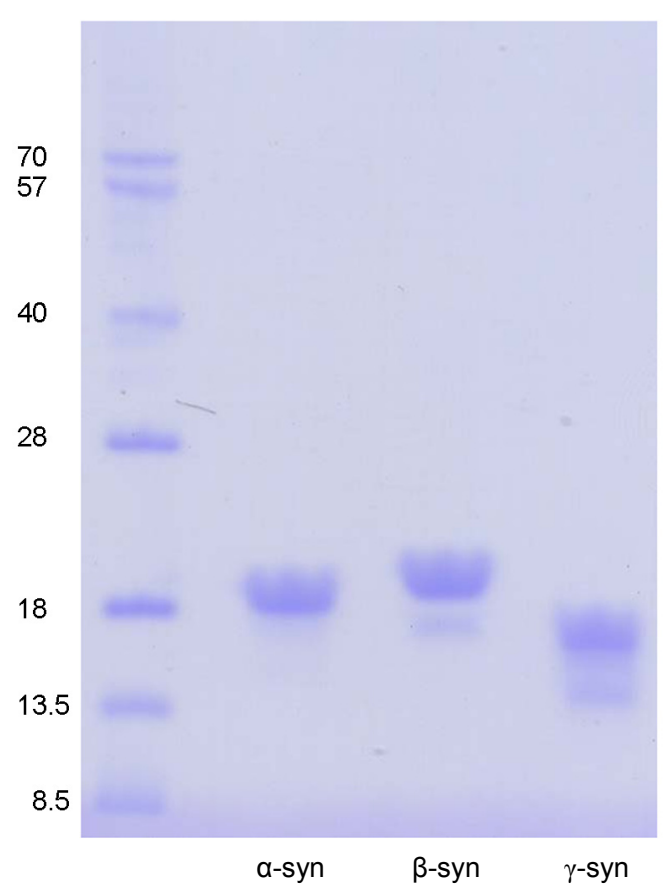

Figure 1. SDS-PAGE analysis of the purified recombinant synucleins. The purified recombinant synucleins were separated by $15 \%$ SDS-PAGE and stained with Coomassie brilliant blue. $\alpha$-synuclein ( $\alpha$-syn), $\beta$-synuclein ( $\beta$-syn), and $\gamma$-synuclein $(\gamma$-syn).

이 0.001 보다 작은 경우는 **로 표시하였다.

\section{결 과}

\section{재조합 synuclein 단백질의 정제}

재조합 synuclein DNA로 형질전환된 E. coli에서 얻은 단백질은 이온교환 크로마토그래피 분리법과 크기에 따 른 gel filtration 크로마토그래피 분리법을 통해 정제하였 다 (42). 두 번의 정제과정 후 SDS-PAGE를 통해 확인한 결과 재조합 $\alpha-, \beta-, \gamma$-synuclein 단백질의 띠가 $18 \sim 20 \mathrm{kDa}$ 에 존재하는 것을 확인하였고 순도는 $90 \%$ 이상으로 나 타났다(Fig. 1).

대장균은 그람음성균으로 내독소인 지질다당류를 포함 하므로 대장균을 통해 얻은 재조합 단백질에는 내독소가 포함되어 있을 수 있다. Peptidoglycan과 지질다당류는 결 장암, 유방암 등의 종양세포의 Toll-like receptor (TLR)와 의 결합을 통해 전이가 촉진된다는 보고가 있다 (43 45). 따라서 정제한 재조합 synuclein 단백질만의 순수한 영 향을 알아보기 위해서는 내독소의 제거가 필요하였고, 본 실험에서는 내독소 제거를 위해 Detoxi-Gel Endotoxin
Table 1. Endotoxin contents of before and after removing the endotoxin from the purified recombinant synucleins. For removing the endotoxin, the recombinant synucleins were reacted in Detoxi-Gel Endotoxin Removing Column. Before and after removing the endotoxin, endotoxin contents were quantified by LAL test.

\begin{tabular}{cccc}
\hline \hline \multirow{2}{*}{ Protein } & \multicolumn{2}{c}{ Endotoxin level (EU/ml) } & \multirow{2}{*}{$\begin{array}{c}\text { Percent } \\
\text { reduction }\end{array}$} \\
\cline { 2 - 3 } & Before & After & \\
\hline$\alpha$-synuclein & 3.298 & 0.197 & $\sim 94 \%$ \\
$\beta$-synuclein & 3.336 & 0.125 & $\sim 96 \%$ \\
$\gamma$-synuclein & 2.646 & 0.203 & $\sim 92 \%$ \\
\hline
\end{tabular}

Removing Column을 사용하였다 (46). 내독소 제거 전후 에 재조합 synuclein 단백질에 포함된 내독소의 함량은 LAL test를 통해 측정하였다 (47). LAL test로 정량한 결과, Detoxi-Gel Endotoxin Removing Column 통과 후 내독소 의 양이 $90 \%$ 이상 줄어들어 $1 \mathrm{EU} / \mathrm{ml}$ 이하 값이 나왔다 (Table 1).

재조합 synuclein 단백질에 의한 종양세포의 운동성 증가

$\gamma$-synuclein에 의해서 종양세포의 전이가 촉진된다고 알려져 있다 $(19,29)$. 이를 바탕으로 본 연구에서는 $\gamma$ synuclein 뿐만 아니라 유사성이 높은 $\alpha$-, $\beta$-synuclein이 종양세포의 운동성에 어떤 영향을 미치는지 알아보기 위하여 wound healing assay를 수행하였다. Wound healing assay에 사용한 세포주는 SKOV-3, MDAMB-231, HeLa를 사용하였다. Wound gap은 $2.0 \mathrm{~mm}$ 로 생성하고, 재조합 $\alpha$-, $\beta$-, $\gamma$-synuclein 단백질을 각각 $100 \mathrm{nM}$ 과 $500 \mathrm{nM}$ 로 처리하 여 0시간과 24시간이 지난 후에 같은 위치에서 사진을 촬영하였다. 0 시간과 24 시간일 때의 사진을 통해 wound gap 면적의 차이를 ImageJ 프로그램을 통해 control과 비 교하여 정량화 하였다. 실험 결과, SKOV-3 세포는 100 $\mathrm{nM}$ 의 재조합 synuclein 단백질을 처리한 값은 control에 비해 $\alpha$-, $\beta, \gamma$-synuclein 공히 약 $25 \%$ 정도 증가하였고, $500 \mathrm{nM}$ 로 처리한 값은 $40 \%$ 이상 증가하였다. 그림을 통 해서도 control에 비해 재조합 synuclein 단백질을 처리한 group에서 wound gap이 줄어든 차이를 확연히 보여주고 있다(Fig. 2A, B). MDAMB-231 세포에 $100 \mathrm{nM}$ 의 재조합 synuclein 단백질을 처리한 값은 $\alpha-, \beta-, \gamma$-synuclein 공히 control에 비해 약 $10 \%$ 정도 증가하였고, $500 \mathrm{nM}$ 로 처리 한 값은 $20 \%$ 이상 증가하였다(Fig. $2 \mathrm{C}$ ). 실제로 재조합 
A

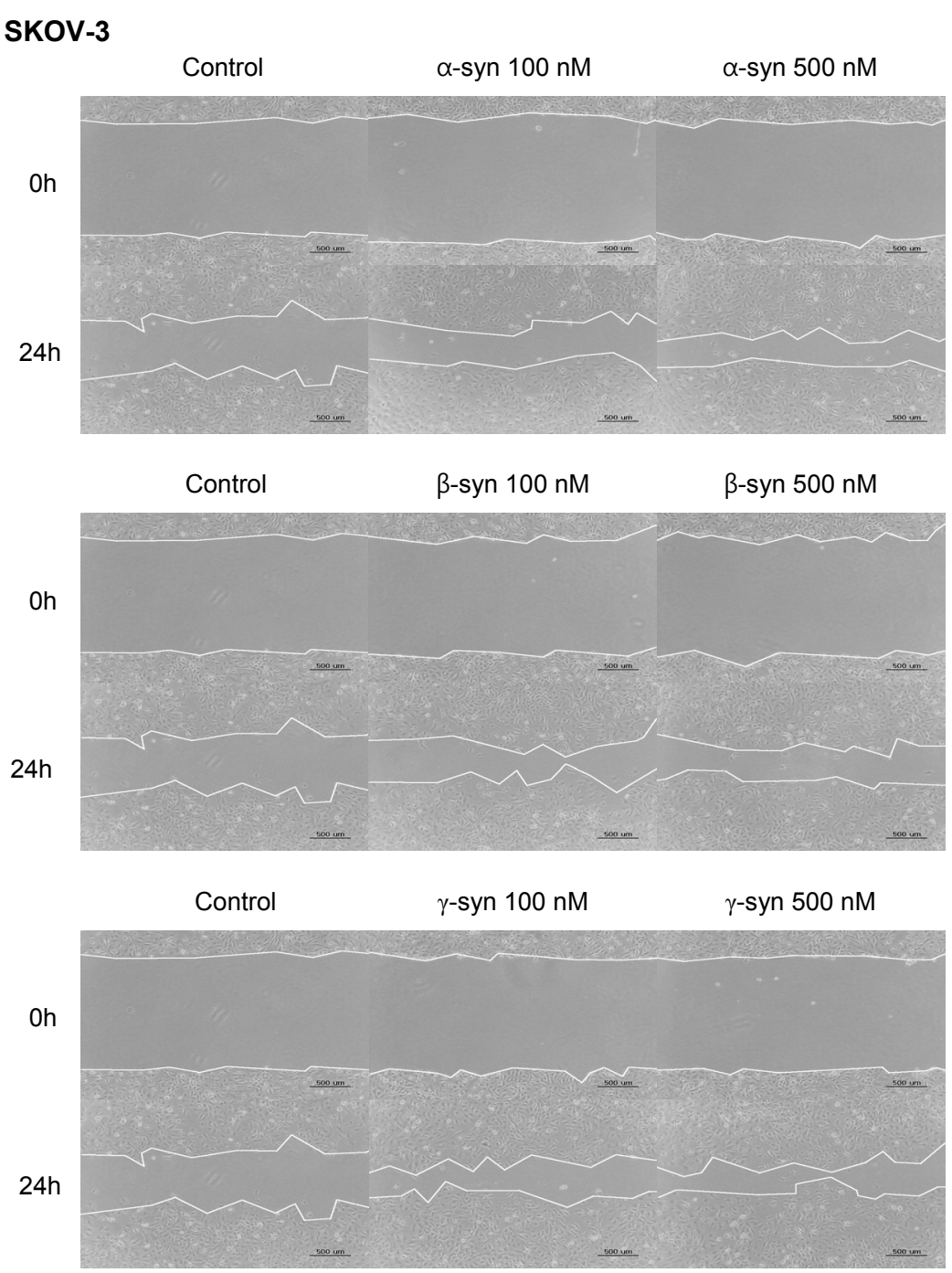

B

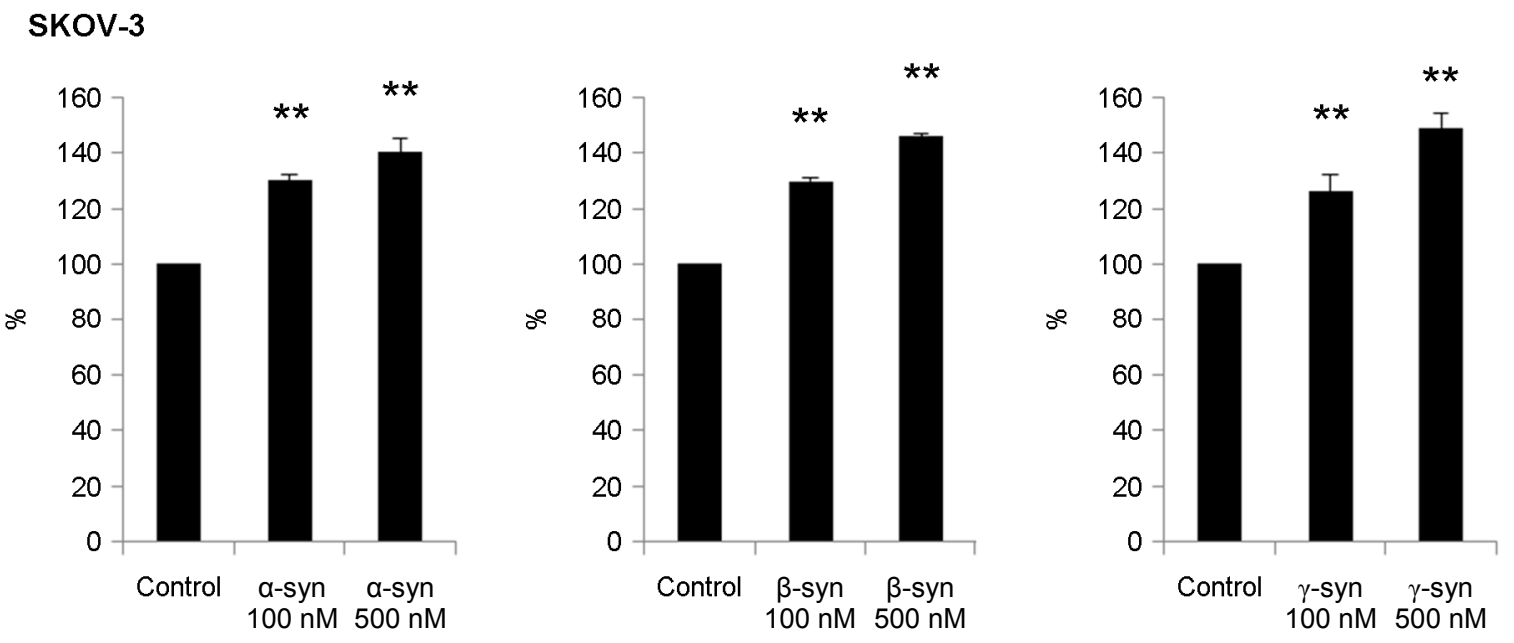


C

\section{MDAMB-231}
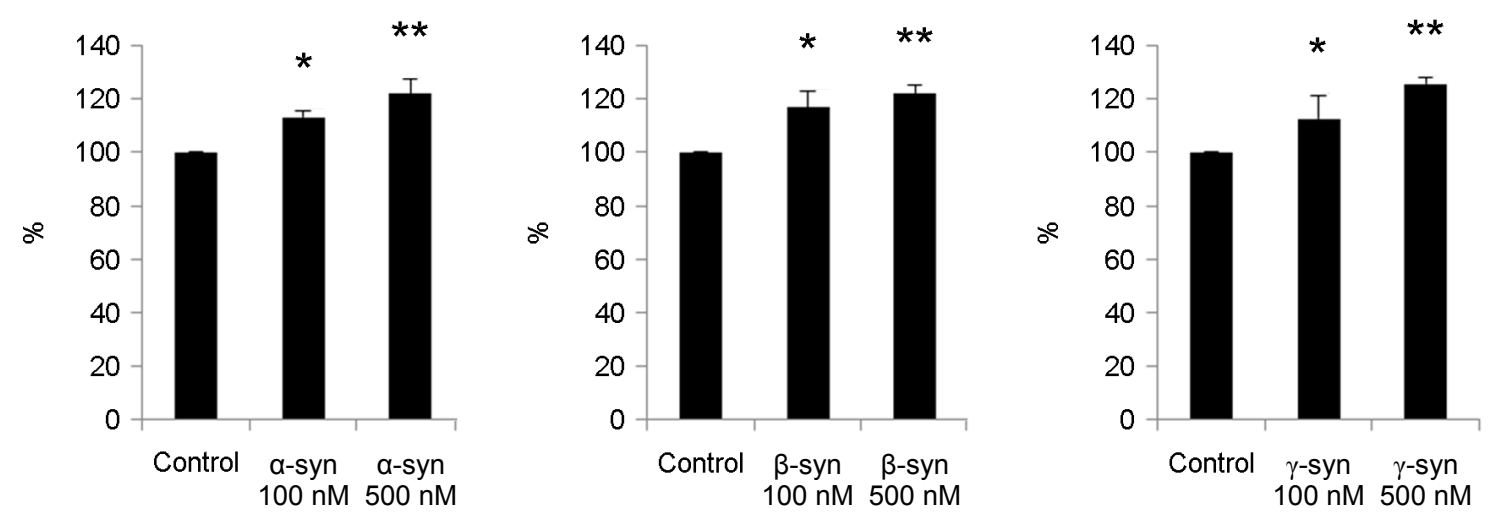

(D)

\section{HeLa}
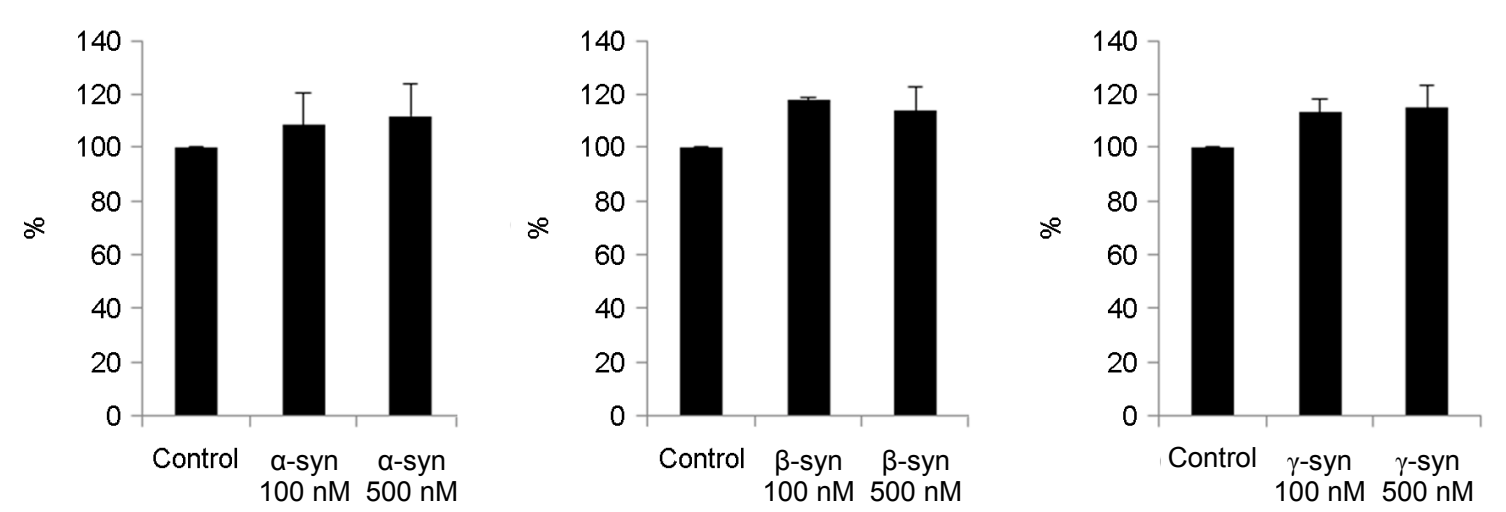

Figure 2. The recombinant synucleins induced cancer cell migration. SKOV-3, MDAMB-231, HeLa cells were treated with $100 \mathrm{nM}$ and $500 \mathrm{nM}$ of the recombinant synucleins for $24 \mathrm{~h}$. (A) The wound gaps of SKOV-3 cells at $0 \mathrm{~h}$ and $24 \mathrm{~h}$. The gaps of $0 \mathrm{~h}$ and $24 \mathrm{~h}$ were compared by ImageJ. (B) SKOV-3, (C) MDAMB-231, (D) HeLa cells were quantified $(\mathrm{n}=3)$. Scale bar, $500 \mu \mathrm{m}$. ${ }^{*} p<0.05,{ }^{* *} p<0.001$.

synuclein 단백질을 $100 \mathrm{nM}$ 로 처리한 group에 비해서 500 $\mathrm{nM}$ 로 처리한 group이 wound gap을 채운 세포가 더 많았 다. $\mathrm{HeLa}$ 세포에 $100 \mathrm{nM}$ 의 재조합 synuclein 단백질을 처 리한 값은 $\alpha$-, $\beta$-, $\gamma$-synuclein 공히 control에 비해 약 $10 \%$ 정도 증가하였고, $500 \mathrm{nM}$ 로 처리한 값 또한 비슷하게 $10 \%$ 정도 증가하였다. 재조합 synuclein 단백질을 $100 \mathrm{nM}$ 과 $500 \mathrm{nM}$ 로 처리한 group간의 차이가 크지 않으나 재 조합 synuclein 단백질을 $\mathrm{HeLa}$ 세포에 처리하면 control 에 비해 세포의 운동성이 증가하였다(Fig. 2D). 이 실험 을 통해 재조합 $\alpha$-, $\beta$-, $\gamma$-synuclein 단백질에 의해 SKOV-3, MDAMB-231, HeLa 종양세포의 운동성이 증가하였음을 알 수 있었고, 이때 $\alpha-, \beta-, \gamma$-synuclein의 효과는 모두 비슷 하게 나타났다.

\section{IGF-|에 의한 종양세포의 운동성 증가}

다음으로 IGF-I을 1 100 ng/ml의 농도범위로 처리하여 종양세포의 운동성에는 어떤 영향을 미치는지 알아보기 위하여 앞서 수행한 wound healing assay와 동일하게 수 행하였다. 실험 결과, SKOV-3 세포는 $1 \mathrm{ng} / \mathrm{ml}$ 의 IGF-I을 처리하면 control에 비해 세포 이동이 $21 \%$ 증가하고, 5 $\mathrm{ng} / \mathrm{ml}$ 의 IGF-I을 처리하면 $25 \%$ 증가하였다. 이후 IGF-I 을 $100 \mathrm{ng} / \mathrm{ml}$ 까지 처리하여도 크게 증가하지 않았다(Fig. 3A, B). MDAMB-231 세포에 $1 \mathrm{ng} / \mathrm{ml}$ 의 IGF-I을 처리하면 control에 비해 세포 이동이 $15 \%$ 증가하고, $5 \mathrm{ng} / \mathrm{ml}$ 의 IGF-I을 처리하면 $14 \%$ 증가하였다. 이후 IGF-I을 100 $\mathrm{ng} / \mathrm{ml}$ 까지 처리하여도 크게 증가하지는 않았다(Fig. $3 \mathrm{C}$ ). $\mathrm{HeLa}$ 세포에 $1 \mathrm{ng} / \mathrm{ml}$ 의 IGF-I을 처리하면 control에 비해 세포 이동이 $15 \%$ 증가하고, $5 \mathrm{ng} / \mathrm{ml}$ 의 IGF-I을 처리하면 
A

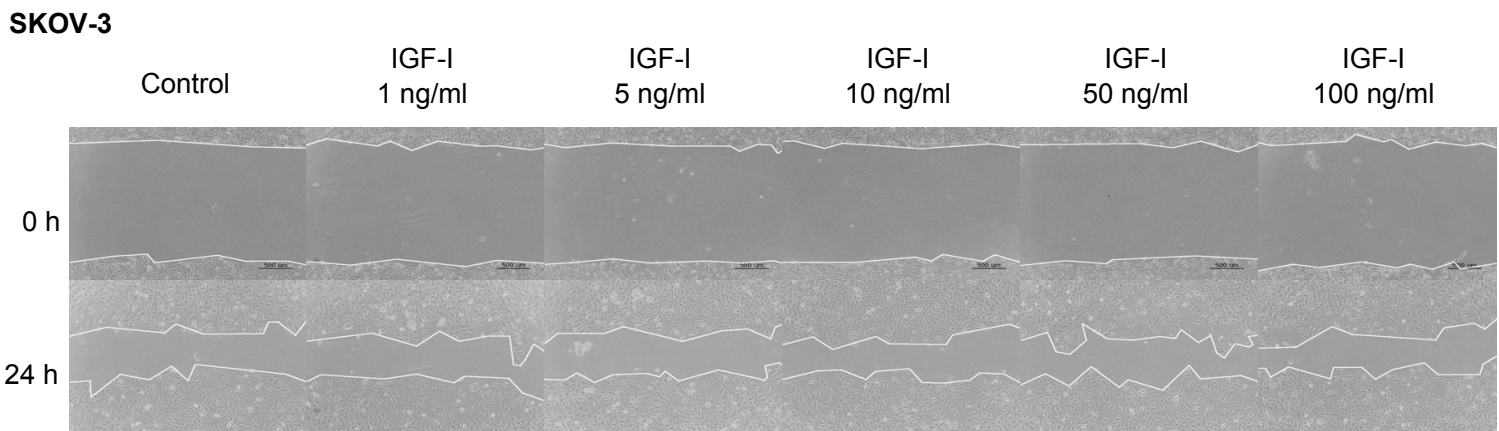

B

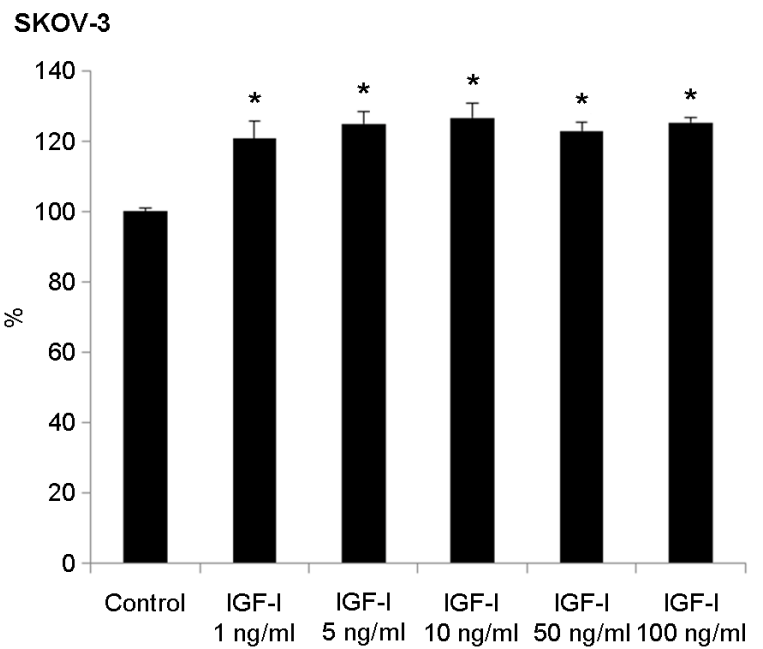

(D)

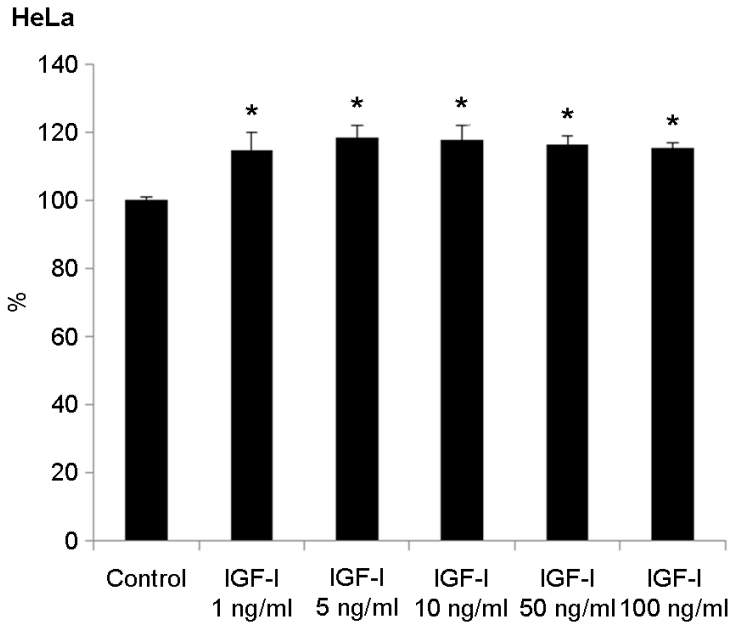

$18 \%$ 증가하였다. SKOV-3 세포나 MDAMB-231 세포와 마 찬가지로 IGF-I을 $100 \mathrm{ng} / \mathrm{ml}$ 까지 처리하여도 크게 증가하 지는 않았다(Fig. 3D). 따라서 $1 \mathrm{ng} / \mathrm{ml}$ 의 IGF-I만 처리해 도 충분히 세포 이동을 촉진하며, IGF-I의 농도를 높여
C

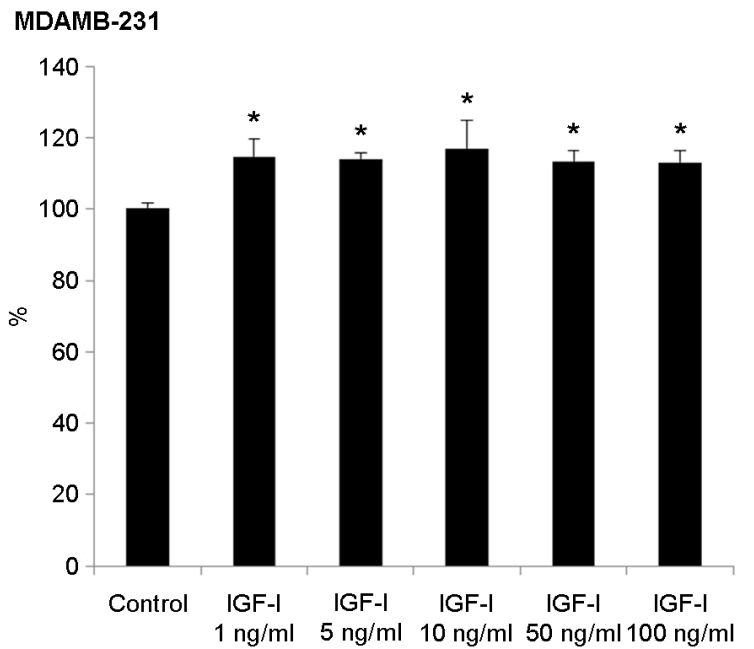

Figure 3. IGF-I induced cancer cell migration. SKOV-3, MDAMB-231, HeLa cells were treated with 1 to $100 \mathrm{ng} / \mathrm{ml}$ of IGF-I for $24 \mathrm{~h}$. (A) The wound gaps of SKOV-3 cells at $0 \mathrm{~h}$ and $24 \mathrm{~h}$. The gaps of $0 \mathrm{~h}$ and $24 \mathrm{~h}$ were compared by ImageJ. (B) SKOV-3, (C) MDAMB-231, (D) HeLa cells were quantified $(\mathrm{n}=3)$. Scale bar, $500 \mu \mathrm{m} .{ }^{*} p<0.05$.

$100 \mathrm{ng} / \mathrm{ml}$ 까지 처리하여도 세포 이동이 계속 증가하지는 않는 것을 알 수 있었다. 
재조합 synuclein 단백질과 IGF-I의 동시 처리에 의 한 종양세포의 운동성 증가

앞선 실험 결과, 재조합 $\alpha-, \beta-, \gamma$-synuclein 단백질을 단 독 처리하거나, IGF-I을 종양세포에 단독 처리하면 종양 세포의 운동성이 증가하였다. 다음으로 재조합 synuclein
단백질과 IGF-I을 같이 종양세포에 처리하였을 때 종양 세포의 운동성을 확인하였다. 종양세포의 운동성을 확인 하기 위하여 앞서 수행한 wound healing assay와 동일하 게 수행하였다. 재조합 $\alpha-, \beta-, \gamma$-synuclein 단백질의 농도 는 $500 \mathrm{nM}, \mathrm{IGF}-\mathrm{I}$ 의 농도는 $5 \mathrm{ng} / \mathrm{ml}$ 을 사용하였다. 실험 결과, SKOV-3 세포는 IGF-I만 처리한 group은 control에

A

SKOV-3

Control

IGF-I

IGF-I $+\alpha$-syn

IGF-I + $\beta$-syn

IGF-I + $\gamma$-syn

$\mathrm{Oh}$

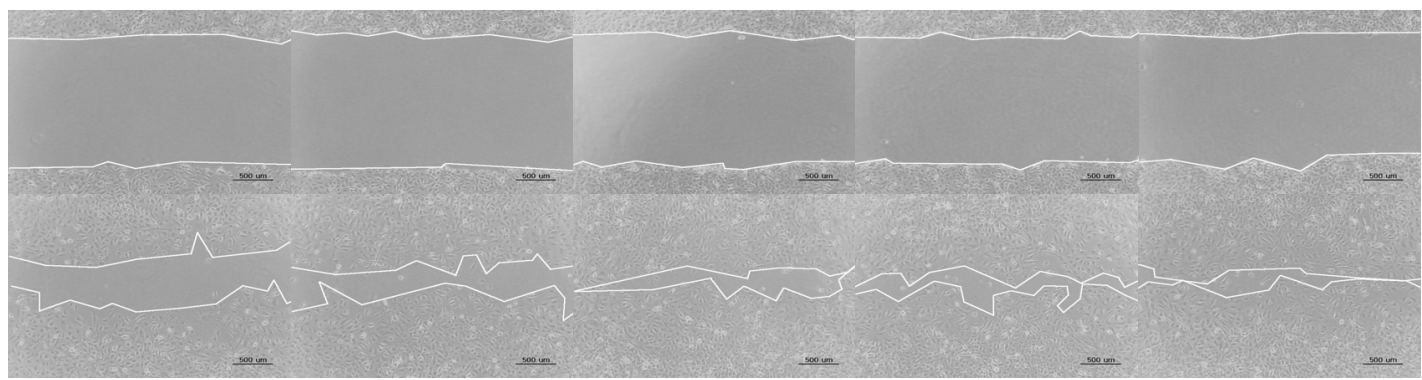

B

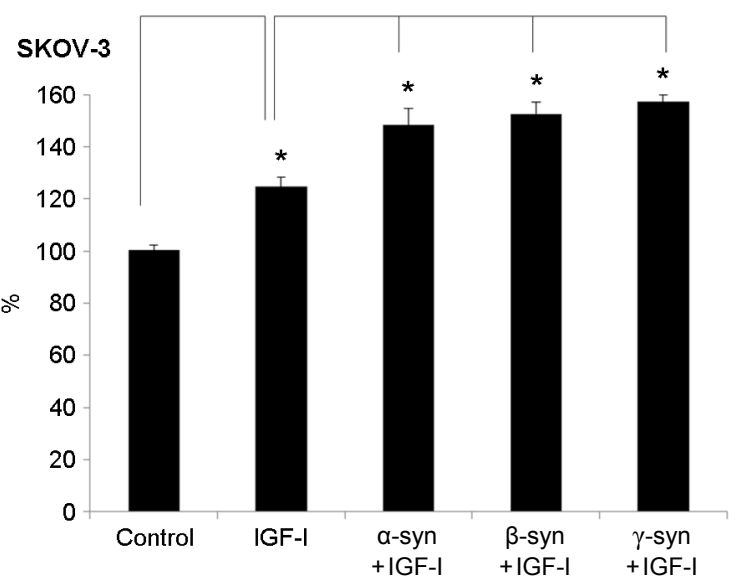

(D)

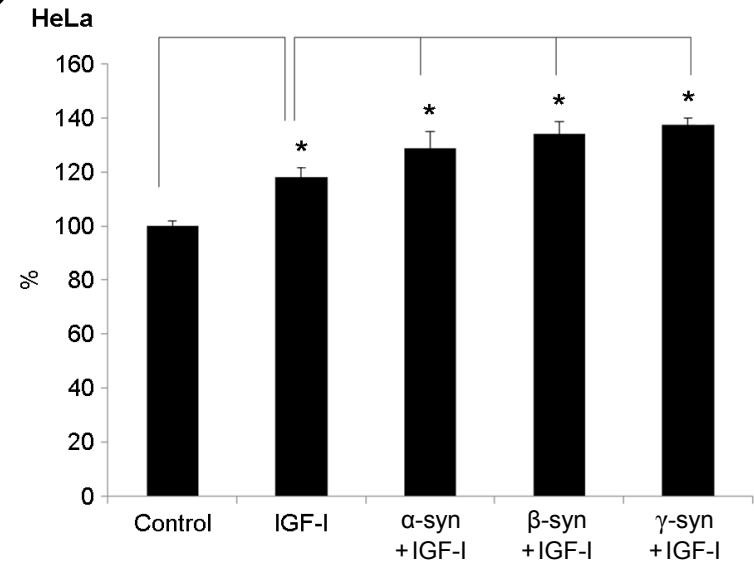

C

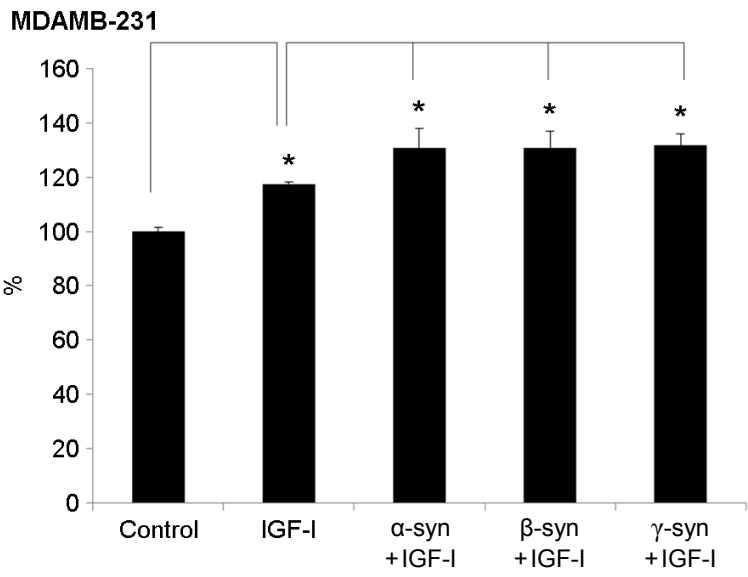

Figure 4. The recombinant synucleins and IGF-I induced cancer cell migration. SKOV-3, MDAMB-231, HeLa cells were treated with $5 \mathrm{ng} / \mathrm{ml}$ of IGF-I and $500 \mathrm{nM}$ of the recombinant synucleins for $24 \mathrm{~h}$. (A) The wound gaps of SKOV-3 cells at $0 \mathrm{~h}$ and $24 \mathrm{~h}$. The gaps of $0 \mathrm{~h}$ and $24 \mathrm{~h}$ were compared by ImageJ. (B) SKOV-3, (C) MDAMB-231, (D) HeLa cells were quantified $(\mathrm{n}=3)$. Scale bar, $500 \mu \mathrm{m}$. ${ }^{*} p<$ 0.05 . 
비해 약 $25 \%$ 정도 증가하였고, 재조합 synuclein 단백질 과 IGF-I이 같이 처리한 group은 $\alpha-, \beta-, \gamma$-synuclein 공히 약 $50 \%$ 정도 증가하였다(Fig. $4 \mathrm{~A}, \mathrm{~B}$ ). MDAMB-231 세포 는 IGF-I을 처리한 group보다 재조합 synuclein 단백질과 IGF-I을 같이 처리한 group에서 세포의 운동성이 더 크 게 증가하였다. IGF-I만 처리한 group은 control에 비해 약 $15 \%$ 정도 증가하였고, 재조합 synuclein 단백질과 IGF-I 이 같이 처리한 group은 $\alpha-, \beta-, \gamma$-synuclein 공히 약 $30 \%$ 정도 증가하였다(Fig. $4 \mathrm{C}$ ). HeLa 세포에 IGF-I만 처리한 group은 control에 비해 약 $15 \%$ 정도 증가하였고, 재조 합 synuclein 단백질과 IGF-I이 같이 처리한 group은 $\alpha$-, $\beta-, \gamma$-synuclein 공히 약 $30 \%$ 정도 증가하였다(Fig. $4 \mathrm{D}$ ). SKOV-3 세포는 약 $25 \%$ 정도 증가하였고, MDAMB-231, $\mathrm{HeLa}$ 세포는 재조합 synuclein 단백질과 IGF-I이 같이 처 리하면 IGF-I만 처리한 group보다 약 $15 \%$ 정도 증가하였 다. 결과를 종합하면, SKOV-3, MDAMB-231, HeLa 세포는 IGF-I에 의해서 세포 운동성이 증가하고, 재조합 $\alpha-, \beta-$, $\gamma$-synuclein 단백질과 IGF-I을 같이 처리하면 IGF-I만 처 리한 group보다 세포 운동성이 더 증가하였음을 알 수 있었고, 이때도 $\alpha-, \beta-, \gamma$-synuclein의 효과는 모두 비슷함 을 알 수 있었다.

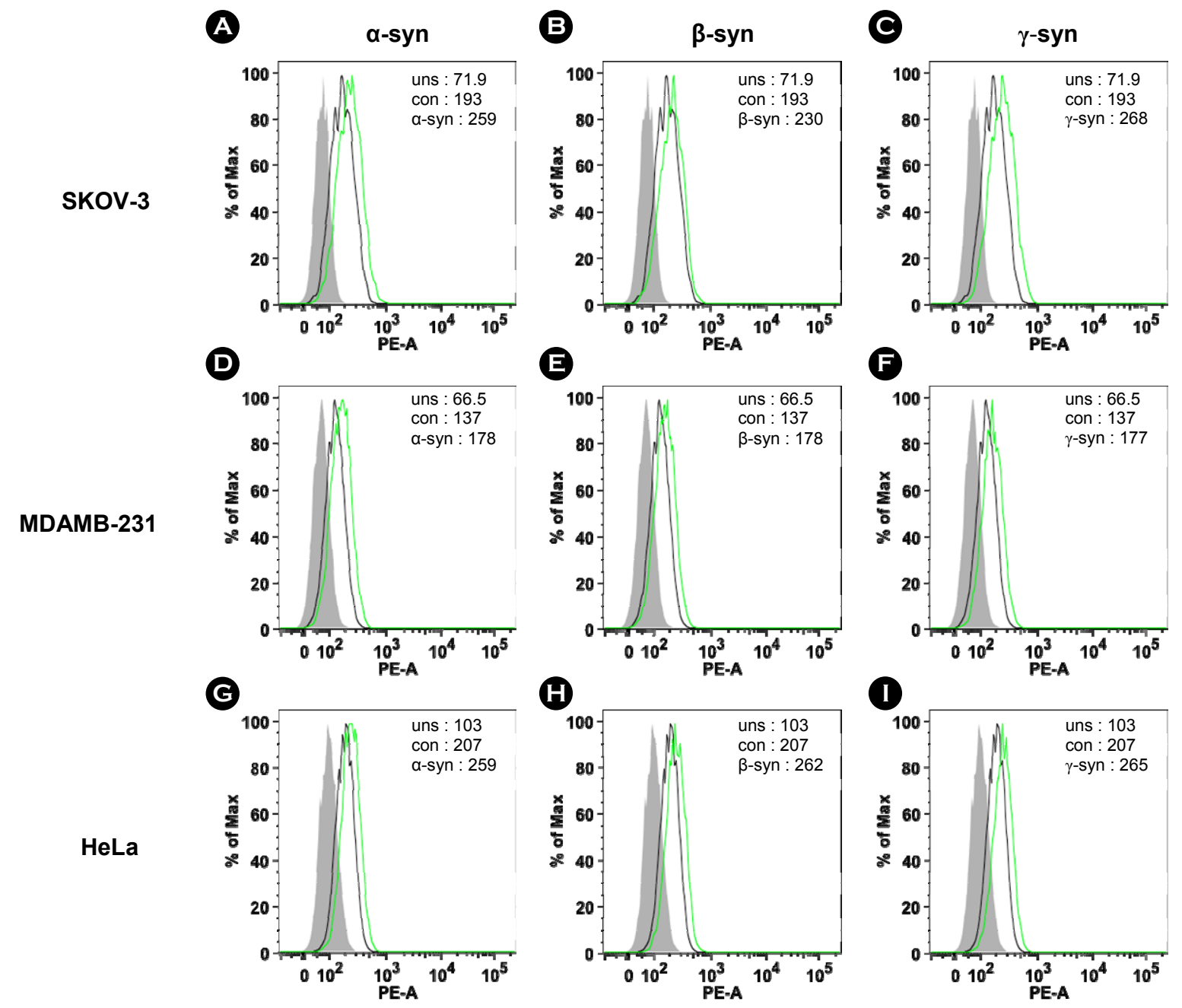

Figure 5. The recombinant synucleins induced the expression of MT1-MMP. For investigation of the expression of MT1-MMP, FACS analysis was accomplished. SKOV-3 cells were treated with $500 \mathrm{nM}$ of (A) $\alpha$-synuclein, (B) $\beta$-synuclein, and (C) $\gamma$-synuclein for $24 \mathrm{~h}$. MDAMB-231 cells were treated with $500 \mathrm{nM}$ of (D) $\alpha$-synuclein, (E) $\beta$-synuclein, and (F) $\gamma$-synuclein for $24 \mathrm{~h}$. HeLa cells were treated with $500 \mathrm{nM}$ of (G) $\alpha$-synuclein, (H) $\beta$-synuclein, and (I) $\gamma$-synuclein for $24 \mathrm{~h}$. Solid gray, unstained (uns). Tinted gray with line, control (con). Bold black line, recombinant synucleins. 


\section{$\mathrm{MT1}-\mathrm{MMP}$ 와 CD44 발현량}

전이와 관련된 표면 단백질 중에 전이를 촉진하는 것 으로 잘 알려진 물질은 $\mathrm{MMP}$ 이다. $\mathrm{MMP}$ 는 $\mathrm{ECM}$ 을 분해 하여 종양세포의 전이를 일으킨다는 보고가 있다 (23). 이러한 MMP는 단백질가수분해 효소로 $\mathrm{CD} 44$, proMMP$2, \alpha_{v} \beta_{3}$ integrin, collagen I, TGF- $\beta$, osteopontin 등의 기질을 분해하여 전이를 촉진한다. CD44는 MMP2, MMP7, MMP9, MT1-MMP이 모여 기질을 분해할 수 있는 플랫폼으로 작 용한다. CD44는 또한 MT1-MMP의 기질로 작용하는데, $\mathrm{MT} 1 \mathrm{MMP}$ 가 직접 $\mathrm{CD} 44$ 의 세포 밖 도메인을 먼저 자
르면 세포 안 도메인이 잘려 세포 핵 안으로 들어가서 $\mathrm{CD} 44$ 의 발현을 촉진하는 전사 인자로 작용하여 세포 의 운동성을 증가시킨다. 또한 잘린 세포 안 도메인이 ruffling edge에서 actin cytoskeleton을 앵커링하고, actin 조 절 인자를 리크루팅하여 세포의 운동성을 증가시킨다 는 보고가 있다 (24). 따라서 재조합 synuclein 단백질과 IGF-I에 의해 종양세포의 운동성이 증가되는 기전에 이 들 단백질이 관여하는지를 알아보고자 종양세포의 표면 에 발현하는 단백질인 MT1-MMP와 CD44의 발현의 변 화를 FACS 기법으로 확인하였다.

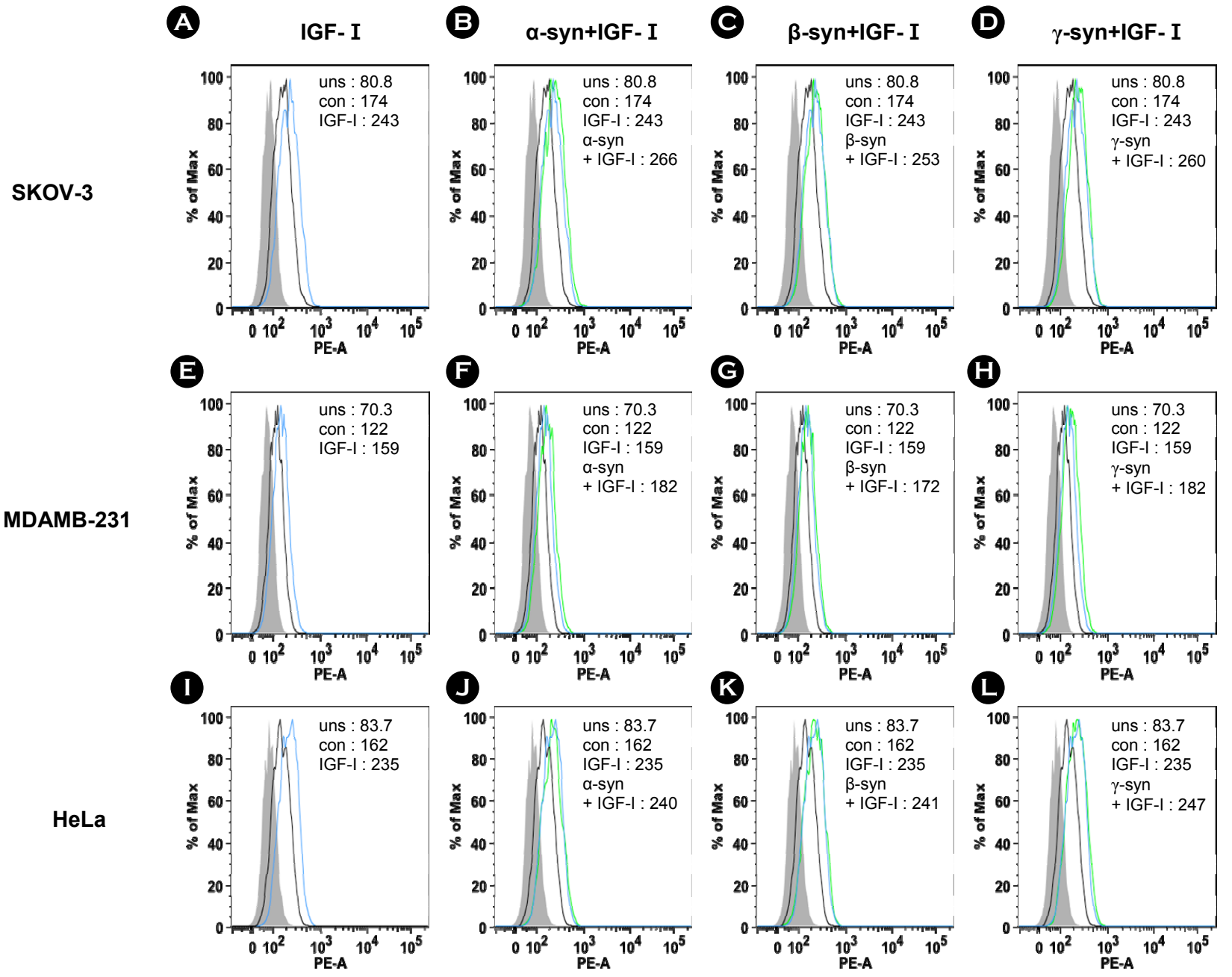

Figure 6. The recombinant synucleins and IGF-I induced the expression of MT1-MMP. For investigation of the expression of MT1MMP, FACS analysis was accomplished. SKOV-3 cells were treated with (A) $5 \mathrm{ng} / \mathrm{ml}$ of IGF-I, $5 \mathrm{ng} / \mathrm{ml}$ of IGF-I and $500 \mathrm{nM}$ of (B) $\alpha$-synuclein, (C) $\beta$-synuclein, and (D) $\gamma$-synuclein for $24 \mathrm{~h}$. MDAMB-231 cells were treated with (E) $5 \mathrm{ng} / \mathrm{ml} \mathrm{of} \mathrm{IGF-I,} 5 \mathrm{ng} / \mathrm{ml}$ of IGF-I and $500 \mathrm{nM}$ of (F) $\alpha$-synuclein, (G) $\beta$-synuclein, and (H) $\gamma$-synuclein for $24 \mathrm{~h}$. HeLa cells were treated with (I) $5 \mathrm{ng} / \mathrm{ml}$ of IGF-I, $5 \mathrm{ng} / \mathrm{ml}$ of IGF-I and $500 \mathrm{nM}$ of (J) $\alpha$-synuclein, (K) $\beta$-synuclein, and (L) $\gamma$-synuclein for $24 \mathrm{~h}$. Solid gray, unstained. Tinted gray with line, control (con). Gray line, IGF-I. Bold black line, recombinant synucleins. 
재조합 synuclein 단백질에 의한 MT1-MMP 발현량 증가

SKOV-3, MDAMB-231, HeLa 세포에 재조합 $\alpha-, \beta-$, $\gamma$-synuclein 단백질 $500 \mathrm{nM}$ 을 처리하여 24 시간 동안 $37^{\circ} \mathrm{C}$, $5 \% \mathrm{CO}_{2}$ 배양기에서 배양하였다. 세포 수는 $5 \times 10^{5}$ 으로 동일하며 MT1-MMP 발현량을 FACS 기법으로 확인하였 다. 실험 결과, SKOV-3, MDAMB-231, HeLa 세포에서 모 두 재조합 $\alpha-, \beta-, \gamma$-synuclein 단백질에 의해 MT1-MMP의 발현량이 증가하였다. SKOV-3 세포는 재조합 synuclein
단백질에 의해 $\alpha-, \beta-, \gamma$-synuclein 공히 $30 \%$ 이상 증가하 였다(Fig. 5A, B, C). MDAMB-231 세포는 재조합 synuclein 단백질에 의해 $\alpha-, \beta-, \gamma$-synuclein 공히 약 $30 \%$ 정도 증가 하였다(Fig. 5D, E, F). HeLa 세포는 재조합 synuclein 단백 질에 의해 $\alpha$-, $\beta$-, $\gamma$-synuclein 공히 약 $25 \%$ 정도 증가하였 다(Fig. 5G, H, I).

재조합 synuclein 단백질과 IGF-|에 의한 MT1-MMP 발현량 증가

SKOV-3, MDAMB-231, HeLa 세포에 $5 \mathrm{ng} / \mathrm{ml}$ 의 IGF-I
A

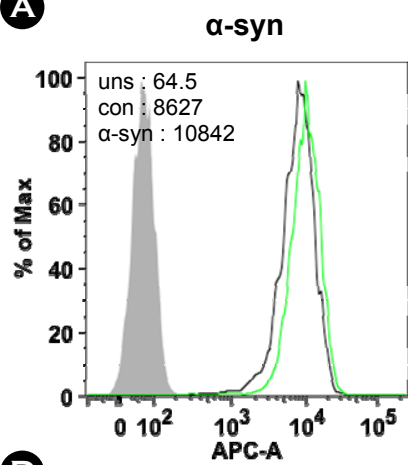

(D)

SKOV-3

MDAMB-231

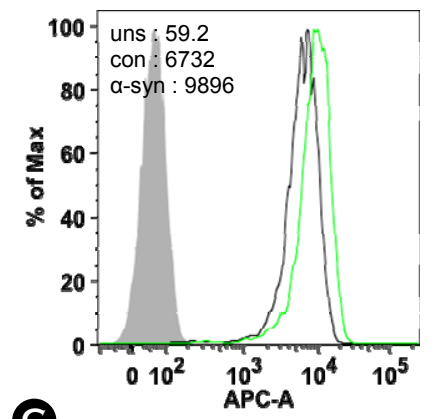

$\boldsymbol{G}$

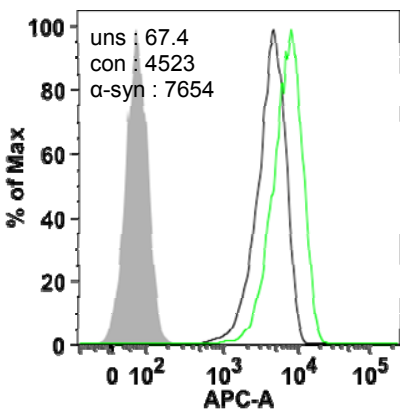

B

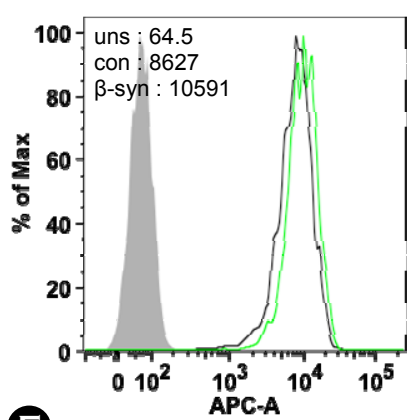

E

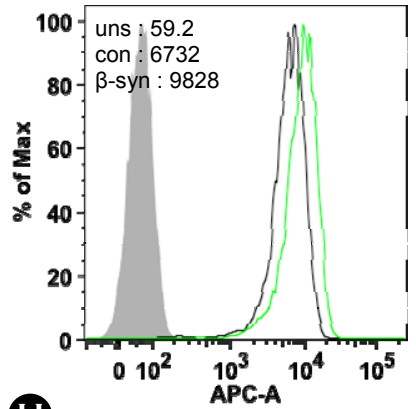

H

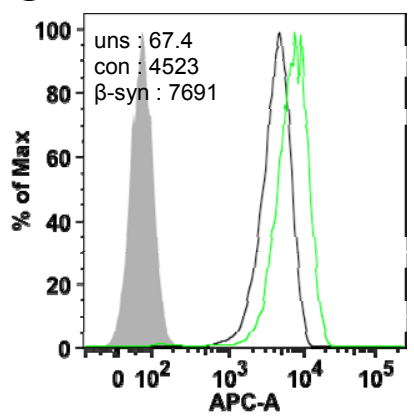

C

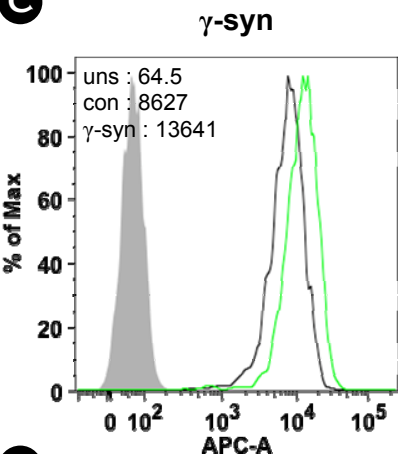

$\boldsymbol{\theta}$

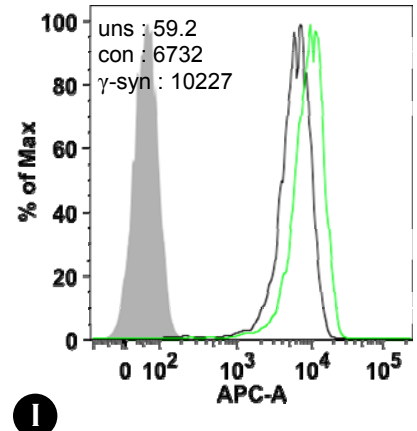

(

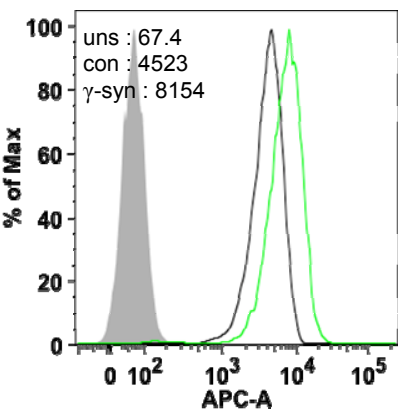

Figure 7. The recombinant synucleins induced the expression of CD44. For investigation of the expression of CD44, FACS analysis was accomplished. SKOV-3 cells were treated with $500 \mathrm{nM}$ of (A) $\alpha$-synuclein, (B) $\beta$-synuclein, and (C) $\gamma$-synuclein for $24 \mathrm{~h}$. MDAMB-231 cells were treated with $500 \mathrm{nM}$ of (D) $\alpha$-synuclein, (E) $\beta$-synuclein, and (F) $\gamma$-synuclein for $24 \mathrm{~h}$. HeLa cells were treated with $500 \mathrm{nM}$ of (G) $\alpha$-synuclein, (H) $\beta$-synuclein, and (I) $\gamma$-synuclein for $24 \mathrm{~h}$. Solid gray, unstained. Tinted gray with line, control (con). Bold black line, recombinant synucleins. 
만 처리하거나, 재조합 $\alpha-, \beta-, \gamma$-synuclein 단백질과 IGF-I 을 같이 처리하여 동일한 방법으로 MT1-MMP의 발현 량을 FACS 기법으로 확인하였다. 실험 결과, SKOV-3, MDAMB- 231, HeLa 세포에서 모두 IGF-I에 의해 MT1$\mathrm{MMP}$ 의 발현량이 증가하였고, 재조합 $\alpha-, \beta-, \gamma$-synuclein 단백질과 IGF-I을 동시에 처리하면 MT1-MMP의 발현이 더 증가하였다. SKOV-3 세포는 IGF-I에 의해 $30 \%$ 이상 증가하였고(Fig. 6A), 재조합 synuclein 단백질과 IGF-I을 동시에 처리하면 $\alpha-, \beta-, \gamma$-synuclein의 경우 공히 약 $50 \%$ 정도 증가하였다(Fig. $6 \mathrm{~B}, \mathrm{C}, \mathrm{D})$. MDAMB-231 세포에서는 IGF-I에 의해 약 $30 \%$ 정도 증가하였고(Fig. 6E), 재조합 synuclein 단백질과 IGF-I을 동시에 처리하면 $\alpha-, \beta-, \gamma-$ synuclein의 경우 공히 $40 \%$ 이상 증가하였다(Fig. $6 \mathrm{~F}, \mathrm{G}$, $\mathrm{H}) \mathrm{HeLa}$ 세포에서는 IGF-I에 의해 약 $40 \%$ 정도 증가하 였고(Fig. 6I), 재조합 synuclein 단백질과 IGF-I을 동시에
처리하면 $\alpha-, \beta-, \gamma$-synuclein의 경우 공히 약 $50 \%$ 정도 증 가하였다(Fig. 6J, K, L).

\section{재조합 synuclein 단백질에 의한 CD44 발현량 증가}

SKOV-3, MDAMB-231, HeLa 세포에 재조합 $\alpha-, \beta-$, $\gamma$-synuclein 단백질 $500 \mathrm{nM}$ 을 처리하여 동일한 방법으로 $\mathrm{CD} 44$ 의 발현량을 $\mathrm{FACS}$ 기법으로 확인하였다. 실험 결 과, SKOV-3, MDAMB-231, HeLa 세포에서 모두 재조합 $\alpha-, \beta-, \gamma$-synuclein 단백질에 의해 CD44의 발현량이 증가 하였다. SKOV-3 세포는 재조합 synuclein 단백질에 의해 $\alpha$-, $\beta$-, $\gamma$-synuclein 공히 $20 \%$ 이상 증가하였다(Fig. 7A, B, C). MDAMB-231 세포는 재조합 synuclein 단백질에 의해 $\alpha$-, $\beta$-, $\gamma$-synuclein 공히 약 $50 \%$ 정도 증가하였다(Fig. 7D, $\mathrm{E}, \mathrm{F}) . \mathrm{HeLa}$ 세포는 재조합 synuclein 단백질에 의해 $\alpha-, \beta-$, $\gamma$-synuclein 공히 $60 \%$ 이상 증가하였다(Fig. $7 \mathrm{G}, \mathrm{H}, \mathrm{I}$ ).
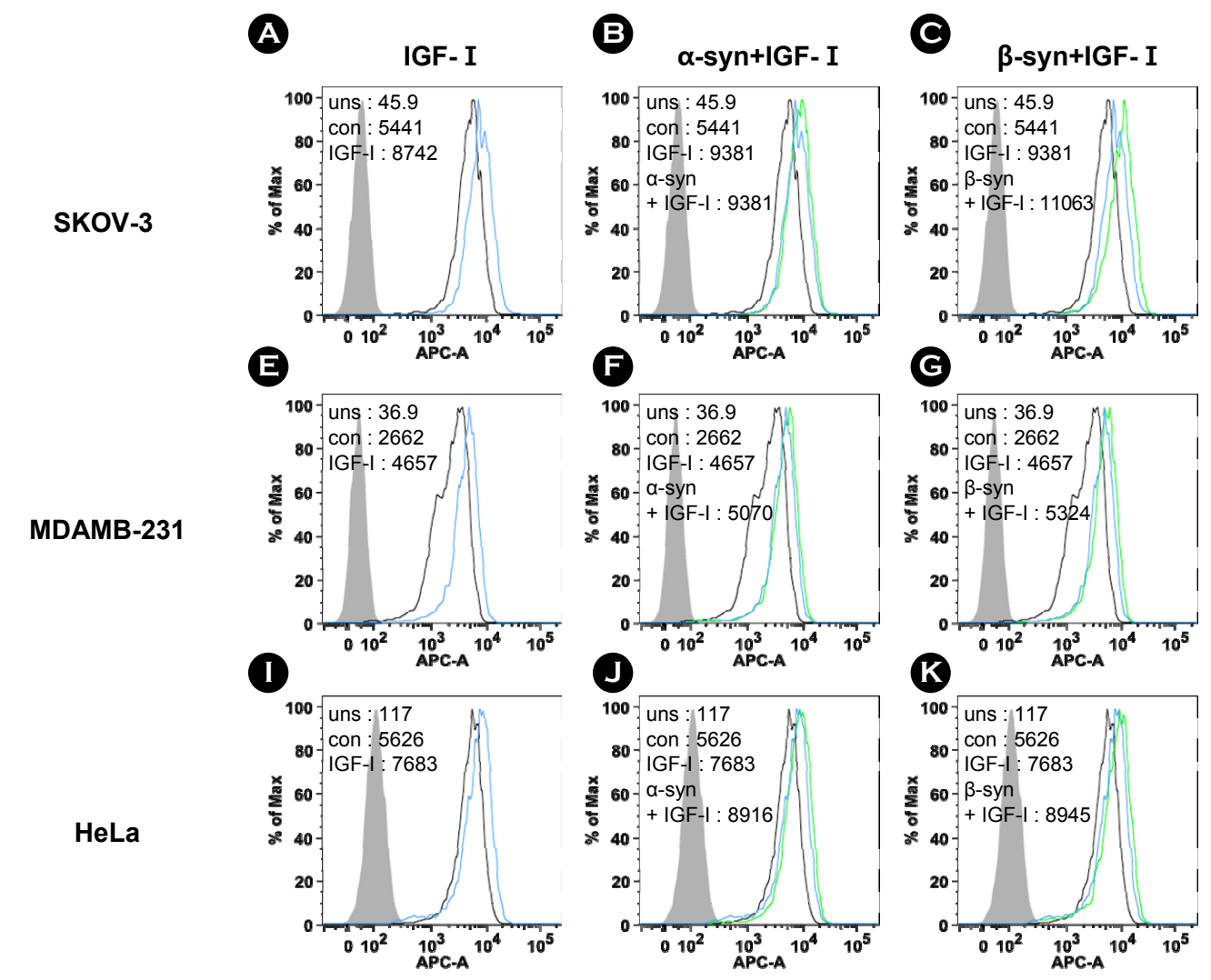

(D) $\gamma$-syn+IGF-I
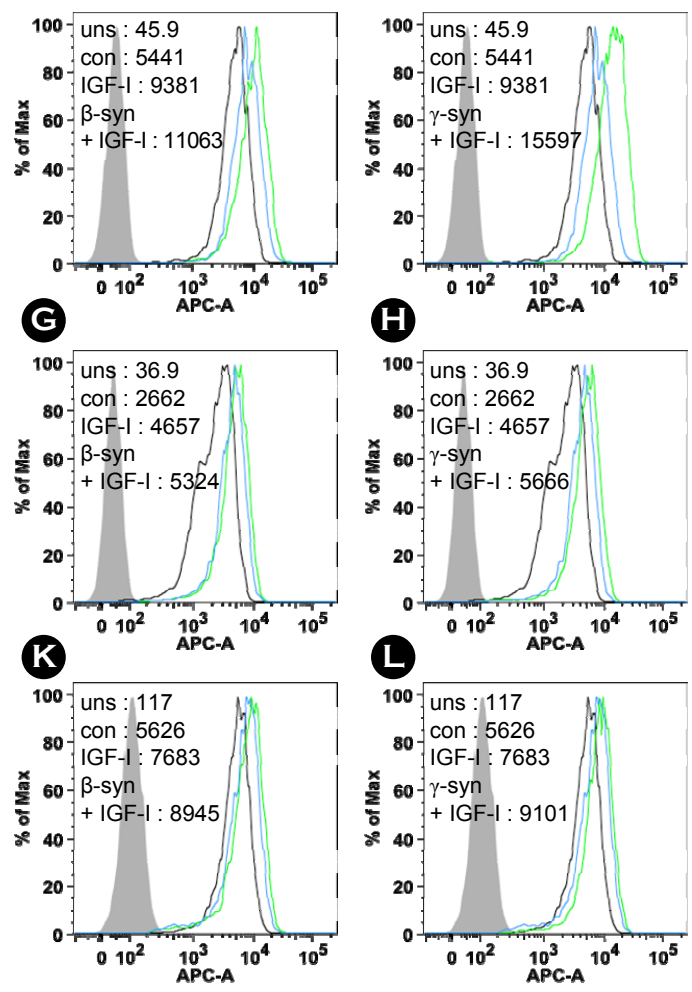

Figure 8. The recombinant synucleins and IGF-I induced the expression of CD44. For investigation of the expression of CD44, FACS analysis was accomplished. SKOV-3 cells were treated with (A) $5 \mathrm{ng} / \mathrm{ml}$ of IGF-I, $5 \mathrm{ng} / \mathrm{ml}$ of IGF-I and $500 \mathrm{nM}$ of (B) $\alpha$-synuclein, (C) $\beta$-synuclein, and (D) $\gamma$-synuclein for $24 \mathrm{~h}$. MDAMB-231 cells were treated with (E) $5 \mathrm{ng} / \mathrm{ml}$ of IGF-I, $5 \mathrm{ng} / \mathrm{ml}$ of IGF-I and $500 \mathrm{nM}$ of (F) $\alpha$-synuclein, (G) $\beta$-synuclein, and (H) $\gamma$-synuclein for $24 \mathrm{~h}$. HeLa cells were treated with (I) $5 \mathrm{ng} / \mathrm{ml}$ of IGF-I, $5 \mathrm{ng} / \mathrm{ml}$ of IGF-I and 500 $\mathrm{nM}$ of (J) $\alpha$-synuclein, (K) $\beta$-synuclein, and (L) $\gamma$-synuclein for $24 \mathrm{~h}$. Solid gray, unstained. Tinted gray with line, control (con). Gray line, IGF-I. Bold black line, recombinant synucleins. 
재조합 synuclein 단백질과 IGF-I에 의한 CD44 발 현량 증가

SKOV-3, MDAMB-231, HeLa 세포에 $5 \mathrm{ng} / \mathrm{ml}$ 의 IGF-I 만을 처리하거나, 재조합 $\alpha-, \beta-, \gamma$-synuclein 단백질과 IGF-I을 같이 처리하여 동일한 방법으로 $\mathrm{CD} 44$ 의 발현 량을 FACS 기법으로 확인하였다. 실험 결과, SKOV-3, MDAMB-231, HeLa 세포에서 모두 IGF-I에 의해 CD44의 발현량이 증가하였고, 재조합 $\alpha-, \beta-, \gamma$-synuclein 단백질과 IGF-I을 동시에 처리하면 CD44의 발현이 더 증가하였다. SKOV-3 세포는 IGF-I에 의해 약 $60 \%$ 정도 증가하였고 (Fig. 8A), 재조합 synuclein 단백질과 IGF-I을 동시에 처 리하면 $\alpha$-synuclein의 경우 약 $70 \%$ 정도 증가하였고, $\beta$ synuclein의 경우 약 $100 \%$ 정도 증가하였고, $\gamma$-synuclein의 경우 약 $180 \%$ 정도 증가하였다(Fig. $8 \mathrm{~B}, \mathrm{C}, \mathrm{D})$. MDAMB231 세포에서는 IGF-I에 의해 약 $70 \%$ 정도 증가하였고 (Fig. 8E), 재조합 synuclein 단백질과 IGF-I을 동시에 처리 하면 $\alpha-, \beta-, \gamma$-synuclein의 경우 공히 $90 \%$ 이상 증가하였다 (Fig. 8F, G, H). HeLa 세포에서는 IGF-I에 의해 약 $30 \%$ 정
도 증가하였고(Fig. 8I), 재조합 synuclein 단백질과 IGF-I 을 동시에 처리하면 $\alpha$-, $\beta$-, $\gamma$-synuclein의 경우 공히 약 $60 \%$ 정도 증가하였다(Fig. $8 \mathrm{~J}, \mathrm{~K}, \mathrm{~L}$ ).

재조합 synuclein 단백질과 IGF-I에 의한 membrane ruffling

최근에 발표된 연구에 의하면 IGF-I 신호기전에 의해 $\mathrm{Akt}$ 가 활성화 되면서 종양세포의 membrane ruffling 형성 이 일어난다고 밝혀졌다 (48). Membrane ruffling 형성은 lamellipodium의 연장이 일어나고 actin이 소중합체, 중합 체를 이루면서 actin filament가 형성되어 세포 형태의 변 형을 일으킨다. IGF-I을 처리하면 세포의 형태는 보통 별 모양으로 움츠러들거나 부채꼴 모양으로 넓게 퍼짐으로 써 변한다. 이와 같이 actin의 구조가 변하여 세포의 형 태가 변하면서 운동성을 갖는다고 알려지고 있다 (48). SKOV-3 세포에 재조합 $\alpha-, \beta-, \gamma$-synuclein 단백질 500 $\mathrm{nM}$ 을 처리를 하거나, $5 \mathrm{ng} / \mathrm{ml}$ 의 IGF-I만을 처리하거나, 재조합 $\alpha-, \beta-, \gamma$-synuclein 단백질과 IGF-I을 같이 처리하 여 membrane ruffling 형성을 확인하였다. SKOV-3 세포
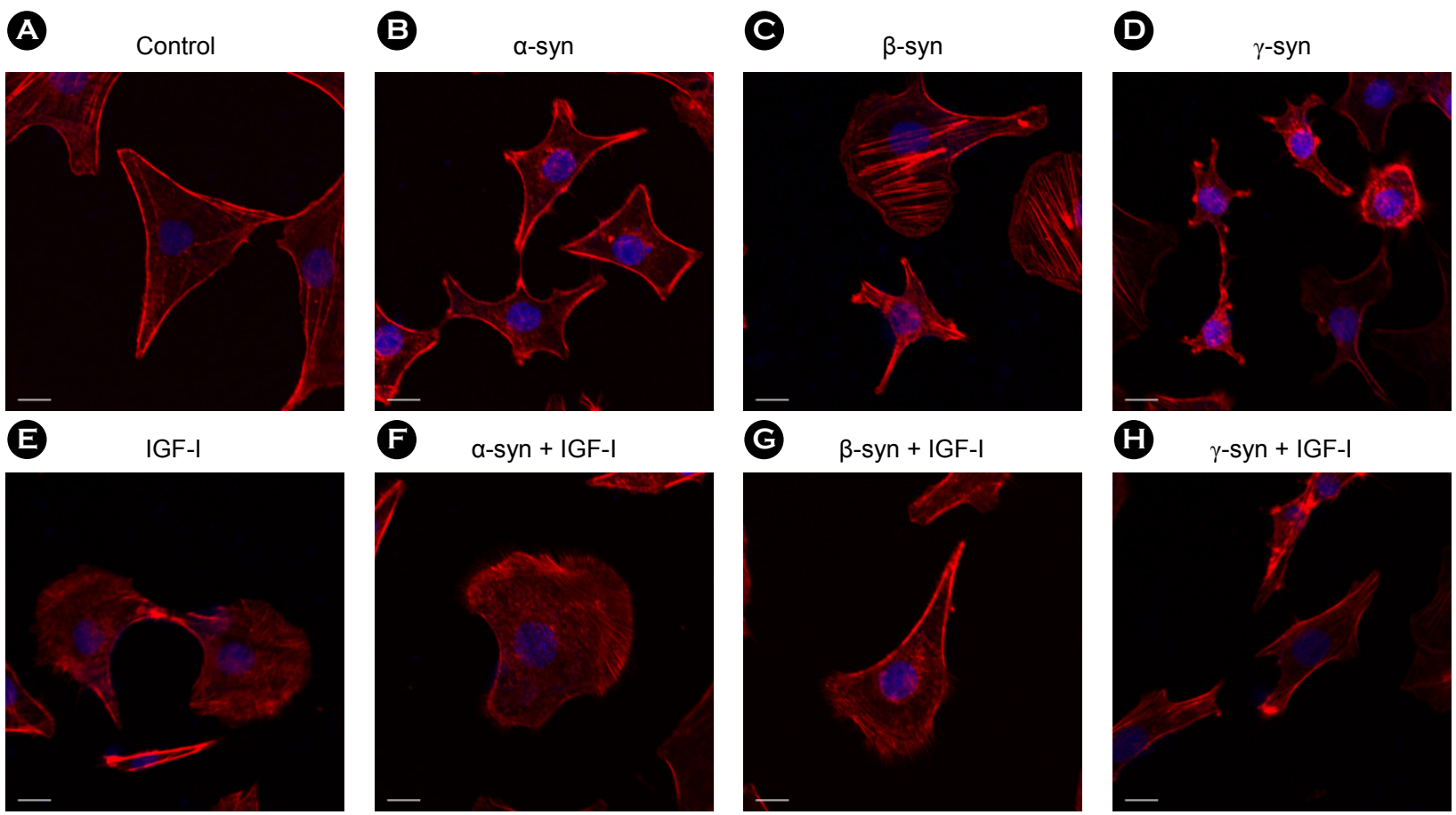

Figure 9. The recombinant synucleins and IGF-I induced the membrane ruffling formation of SKOV-3. For investigation of the membrane ruffling formation, confocal microscopy was accomplished. (A) as control. SKOV-3 cells were treated with $500 \mathrm{nM}$ of (B) $\alpha$-synuclein, (C) $\beta$-synuclein, and (D) $\gamma$-synuclein, (E) $5 \mathrm{ng} / \mathrm{ml}$ of IGF-I, $5 \mathrm{ng} / \mathrm{ml}$ of IGF-I and $500 \mathrm{nM}$ of (F) $\alpha$-synuclein, (G) $\beta$-synuclein, and $(\mathrm{H}) \gamma$-synuclein for $24 \mathrm{~h}$. For F-actin staining, cells were stained with rhodamine phalloidin. Scale bar, $20 \mu \mathrm{m}$. 
에 rhodamine phalloidin으로 F-actin을 염색하여 confocal microscope으로 관찰하였다. 실험 결과, control은 세포가 별 모양으로 움츠러들거나 부채꼴 모양으로 넓게 퍼지지 않고(Fig. 9A), 재조합 $\alpha-, \beta-, \gamma$-synuclein 단백질을 처리하 면 세 경우 모두 세포의 형태가 별 모양으로 움츠러들 고 끝 부분에 actin이 모여서 존재하였다(Fig. 9B, C, D). IGF-I을 처리하면 세포의 형태가 부채꼴 모양으로 넓게 퍼진 부분에 actin filament가 뻗쳐서 존재하였다(Fig. 9E). 재조합 synuclein 단백질과 IGF-I을 같이 처리하면 $\alpha-, \beta-$, $\gamma$-synuclein의 경우 공히 세포의 형태가 부채꼴 모양으로 넓게 퍼진 부분에 actin filament가 뻗쳐서 존재하기도 하 고, 별 모양으로 움츠러들고 끝 부분에 actin이 모여서 존재하였다(Fig. 9F, G, H). 이를 통해 재조합 $\alpha-, \beta-, \gamma-$ synuclein 단백질과 IGF-I는 SKOV-3 세포의 membrane ruffling 형성을 유도하는 것으로 볼 수 있다.

\section{고 찰}

$\gamma$-synuclein 단백질이 과 발현되어 있는 유방암 세포에 서 증식과 전이가 촉진되고, 항암제에 대한 저항성이 증 가된다는 보고가 있다 (20). 또한 $\alpha$-synuclein 단백질이 과 발현되어 있는 소신경교세포에서 전이가 촉진된다는 보 고도 있다 (28). 이러한 결과를 바탕으로 본 연구에서는 $\gamma$-synuclein 뿐만 아니라 유사성이 높은 $\alpha$-, $\beta$-synuclein이 종양세포의 운동성에 미치는 영향을 알아보고자 하였다. 또한 종양세포의 증식과 전이에 관여하고 $\gamma$-synuclein 과 상호작용을 하는 IGF-I과 synuclein family가 종양세 포의 운동성에 미치는 영향을 비교하고자 하였다. 또한 synuclein family와 IGF-I이 종양세포의 운동성에 미치는 영향의 분자기전을 알아보고자 본 실험을 수행하였다.

재조합 synuclein 단백질과 IGF-I에 의한 종양세포의 운 동성을 확인하기 위하여 wound healing assay를 수행하였 다. 실험 결과, SKOV-3 세포는 재조합 synuclein 단백질 을 $100 \mathrm{nM}$ 로 처리한 값은 $\alpha-, \beta-, \gamma$-synuclein 공히 control 에 비해 약 $25 \%$ 정도 증가하였고, $500 \mathrm{nM}$ 로 처리한 값 은 $40 \%$ 이상 증가하였다. MDAMB-231 세포는 재조합 synuclein 단백질을 $100 \mathrm{nM}$ 로 처리한 값은 $\alpha-, \beta-, \gamma-$ synuclein 공히 control에 비해 약 $10 \%$ 정도 증가하였고, $500 \mathrm{nM}$ 로 처리한 값은 $20 \%$ 이상 증가하였다. $\mathrm{HeLa}$ 세 포는 재조합 synuclein 단백질을 $100 \mathrm{nM}$ 로 처리한 값은 $\alpha-, \beta-, \gamma$-synuclein 공히 control에 비해 약 $10 \%$ 정도 증
가하였고, $500 \mathrm{nM}$ 로 처리한 값 또한 $10 \%$ 정도 증가하 였다. SKOV-3, MDAMB-231, HeLa 세포 모두에서 재조합 synuclein 단백질을 처리하면 control에 비해 세포 운동 성이 증가하였다. 또한 재조합 synuclein 단백질을 높은 농도로 처리한 group에서 세포 운동성이 더 증가하였다 (Fig. 2). 반면, $5 \mathrm{ng} / \mathrm{ml}$ 의 IGF-I을 SKOV-3 세포에 단독적 으로 처리하면 control에 비해 약 $25 \%$ 정도 증가하였 고, $\mathrm{MDAMB}-231$ 과 $\mathrm{HeLa}$ 세포에 단독적으로 처리하면 control에 비해 약 $15 \%$ 정도 증가하였다. IGF-I의 생물학 적 활성은 1 10 ng/ml까지 농도에 비례하여 세포 운동 성이 증가하였지만, $10 \sim 100 \mathrm{ng} / \mathrm{ml}$ 의 IGF-I 농도로 처리한 group 간에 세포 운동성의 차이는 크지 않았다(Fig. 3). 따 라서 synuclein 단백질과 IGF-I이 종양세포의 운동성에 미 치는 영향을 비교해 보면, $1 \sim 100 \mathrm{ng} / \mathrm{ml}$ 의 IGF-I을 종양세 포에 단독으로 처리하면, $100 \mathrm{nM}$ 의 재조합 synuclein 단 백질을 단독으로 처리한 값과 비슷하고 $500 \mathrm{nM}$ 의 재조 합 synuclein 단백질을 단독으로 처리한 값 보다는 작음 을 알 수 있다. 최근에 $\gamma$-synuclein 단백질과 IGF-I의 상호 조절에 의한 종양세포의 증식과 전이가 촉진된다고 보고 되었다 (41). 앞선 실험 결과, 재조합 synuclein 단백질을 처리를 하거나, IGF-I을 종양세포에 처리를 하면 종양세 포의 운동성이 증가하였다. 이를 통해 재조합 synuclein 단백질과 IGF-I을 같이 종양세포에 처리하여 종양세포의 운동성을 확인하였다. SKOV-3, MDAMB-231, HeLa 세포 에 $500 \mathrm{nM}$ 의 재조합 synuclein 단백질과 $5 \mathrm{ng} / \mathrm{ml}$ 의 IGF-I 을 처리한 결과, IGF-I에 의해서 세포 운동성이 증가하고, 재조합 synuclein 단백질과 IGF-I을 같이 처리하면 IGF-I만 처리한 group보다 세포 운동성이 더 증가하였다(Fig. 4).

재조합 synuclein 단백질과 IGF-I이 종양세포의 운동성 을 증가시키는 분자기전을 알아보고자, 전이와 관련된 표 면 단백질 중 단백질가수분해 효소인 MT1-MMP와 기질 로 작용하는 $\mathrm{CD} 44$ 의 발현을 확인하기 위해 $\mathrm{FACS}$ 분석 법을 수행하였다. 실험 결과, MT1-MMP과 CD44 모두에 서 $500 \mathrm{nM}$ 의 재조합 synuclein 단백질을 처리하면 발현 이 증가하였다. $500 \mathrm{nM}$ 의 재조합 synuclein 단백질과 $5 \mathrm{ng}$ / $\mathrm{ml}$ 의 IGF-I을 종양세포에 처리하면, IGF-I만 처리한 group 보다 재조합 synuclein 단백질이 같이 처리한 group에서 발현이 더 증가하였다(Fig. $5,6,7,8$ ). 세포의 운동성이 생기는 원동력인 actin의 구조적 변화에 따른 membrane ruffling 형성을 알아보고자 confocal microscopy를 수행하 였다. SKOV-3 세포에 $500 \mathrm{nM}$ 의 재조합 synuclein 단백질 
과 $5 \mathrm{ng} / \mathrm{ml}$ 의 IGF-I을 처리하고, rhodamine phalloidin으로 F-actin을 염색하여 confocal microscope으로 관찰하였다. 실험 결과, control은 별 모양으로 움츠러들거나 부채꼴 모양으로 넓게 퍼지지 않으면서 원래의 세포 형태를 유 지하는 반면, 재조합 synuclein 단백질을 처리하면 세포의 형태가 별 모양으로 움츠러들어 끝 부분에 actin이 모여 서 존재하거나, IGF-I을 처리하면 세포의 형태가 부채꼴 모양으로 넓게 퍼진 부분에 actin filament가 뻗쳐서 존재 하였다(Fig. 9). 따라서 재조합 synuclein 단백질과 IGF-I 은 SKOV-3 세포의 membrane ruffling 형성을 유도하여 세 포가 운동성을 갖게 되는 것으로 생각할 수 있다. 이러한 연구 결과는 재조합 synuclein 단백질과 IGF-I은 MT1$\mathrm{MMP}$ 와 $\mathrm{CD} 44$ 의 발현을 촉진시키고, 세포의 membrane ruffling 형성을 유도함으로써 종양세포의 운동성을 증가 시킨다는 것을 보여준다.

본 연구에서는 $\gamma$-synuclein와 더불어 $\alpha$-, $\beta$-synuclein 또 한 종양세포의 운동성에 관여한다고 밝혔다. Synuclein family의 크기는 $\alpha$-synuclein은 140 아미노산, $\beta$-synuclein 은 134 아미노산, $\gamma$-synuclein은 127 아미노산이고, 서로 의 아미노산 배열의 유사성이 매우 높다. $\alpha$-synuclein과 $\beta$-synuclein의 아미노산 배열은 $62 \%$ 동일하고, $\alpha$-synuclein 과 $\gamma$-synuclein은 $55 \%$ 동일한 것으로 밝혀졌다 (49). 또한 3 차 구조는 두 개의 $\alpha$-helix가 구부러져 이어져 있고 카 르복시 꼬리로 이루어진 구조로 서로 매우 유사하다 (50). 이와 같이 synuclein family의 크기, 아미노산 배열, 3차 구조의 유사성이 상당히 높기 때문에, $\alpha$-, $\beta$-synuclein도 $\gamma$-synuclein와 같이 종양세포의 운동성에 관여한다고 생각 된다. 실제로 본 실험에서 $\alpha-, \beta-, \gamma$-synuclein이 종양세포 의 운동성에 미치는 영향은 매우 비슷한 것으로 나타났 다(Fig. 2).

재조합 synuclein 단백질과 IGF-I에 의해 종양세포의 운동성과 분자기전에 관여하는 단백질인 MT1-MMP와 $\mathrm{CD} 44$ 의 발현이 증가하였다. 이 결과 중에서도 종양세 포에 재조합 synuclein 단백질과 IGF-I을 같이 처리하면, IGF-I만 처리한 group보다 종양세포의 운동성과 MT1$\mathrm{MMP}$ 와 $\mathrm{CD} 44$ 의 발현이 더 증가하였다(Fig. 4, 6, 8). 이 러한 현상이 재조합 synuclein 단백질과 IGF-I이 서로 다 른 작용에 의한 것인지, 아니면 서로 같은 작용에 의한 것인 정확히 밝혀지지 않았다. 여성 성호르몬인 estrogen 과 estrogen 수용체 간의 결합에 $\gamma$-synuclein이 관여하여 estrogen 수용체의 신호전달을 촉진한다는 보고가 있다
(51). 이때 $\gamma$-synuclein이 관여하는 기전은 heat shock 단 백질과 함께 estrogen 수용체에 chaperone 작용을 통하여 estrogen 수용체의 결합 친화력을 증가하여 신호전달을 촉진한다고 알려졌다 (52). Synuclein 단백질의 membrane binding 부분은 카르복시 말단으로 알려져 있다 (50). 본 연구 결과도 synuclein 단백질의 카르복시 말단을 통해 세 포막에 존재하는 IGF-I 수용체에 직접 결합하거나 heat shock 단백질과 함께 chaperone 작용을 통해 기질에 대한 결합 친화력을 증가시킴으로써 발생한 현상이라고 생각 해 볼 수 있을 것이다.

$\gamma$-synuclein은 유방암, 난소암, 간암, 위암, 대장암 등의 종양세포에 많이 발현하고 있다 $(13,29,41)$. 이들 암 세 포에서는 종양세포의 증식과 전이에 관여하는 $\gamma$-synuclein 뿐만 아니라 $\alpha-, \beta$-synuclein도 발현하고 있다. 이처럼 synuclein 단백질은 세포에 내생적으로 발현하고 있고, 실 험을 위해 종양세포에 형질주입을 통해 과 발현시켜 연 구를 수행하기도 하였다 $(29,41)$. 하지만 본 연구에서는 재조합 단백질을 정제하여 배지와 함께 세포에서 처리하 였다. 이전에 재조합 $\alpha-, \beta-, \gamma$-synuclein을 배지와 함께 세 포에 처리하면 30 분 이내로 세포막을 투과하고, 세포 밖 으로 분비한다는 보고가 있다 (42). 재조합 synuclein 단백 질을 외부적으로 처리하였을 때, 재조합 synuclein 단백질 이 세포막을 투과할 수 있는 이유는 반복되는 특정 아미 노산 motif인 'KTKEGV'을 갖고 있기 때문이다. $\alpha$-synuclein 은 7개의 'KTKEGV' motif을 갖고 있으며, $\beta$-synuclein과 $\gamma$-synuclein도 갖고 있어 세포막 투과성을 갖는다 (49). 본 실험에서는 재조합 synuclein 단백질을 배지와 함께 세포 외부적으로 처리하여 실험을 수행하였고, 이 방법으로도 실제 synuclein의 효과를 확인할 수 있었다.

본 연구를 통해 재조합 synuclein 단백질과 IGF-I에 의해 종양세포의 운동성이 증가하고, synuclein 단백질과 IGF-I을 함께 처리하면 종양세포의 운동성이 배가 된다 는 사실을 밝혔다. 종양세포의 운동성이 증가되는 분자기 전 중에 하나는 아마도 MT1-MMP와 CD44의 발현이 증 가하여 세포의 actin filament의 구조적 변형을 초래하여 membrane ruffling 형성을 통해 일어나는 것으로 생각된 다. 다른 연구에 의하면 IGF-I에 의해 종양세포의 운동 성이 증가하는 기전으로는 $\mathrm{Akt}$ 의 인산화형이 증가하는 것이 제시되어 있다 (48). 따라서 재조합 synuclein 단백 질과 IGF-I을 세포에 처리하였을 때, Akt의 인산화형의 발현이 어떻게 변하는지 확인하여 좀더 신호전달 체계에 
대한 후속연구가 필요하다. 추가적으로 세포의 운동성을 확인하는 방법을 wound healing assay를 하였는데, 3차원 적인 세포 이동을 확인할 수 있는 chamber migration assay 나 invasion assay를 통하여 세포의 운동성을 확인할 필요 가 있다.

\section{참 고 문 헌}

1) George JM. The synucleins. Genome Biol 2002;3: REVIEWS3002.

2) Weinreb PH, Zhen W, Poon AW, Conway KA, Lansbury PT Jr. NACP, a protein implicated in Alzheimer's disease and learning, is natively unfolded. Biochemistry 1996;35:13709-15.

3) Iwai A, Masliah E, Yoshimoto M, Ge N, Flanagan L, de Silva HA, et al. The precursor protein of non-A beta component of Alzheimer's disease amyloid is a presynaptic protein of the central nervous system. Neuron 1995;14:467-75.

4) Nakajo S, Shioda S, Nakai Y, Nakaya K. Localization of phosphoneuroprotein 14 (PNP 14) and its mRNA expression in rat brain determined by immunocytochemistry and in situ hybridization. Brain Res Mol Brain Res 1994;27:81-6.

5) Forno LS. Neuropathology of Parkinson's disease. J Neuropathol Exp Neurol 1996;55:259-72.

6) George JM, Jin H, Woods WS, Clayton DF. Characterization of a novel protein regulated during the critical period for song learning in the zebra finch. Neuron 1995;15:361-72.

7) Jenco JM, Rawlingson A, Daniels B, Morris AJ. Regulation of phospholipase D2: selective inhibition of mammalian phospholipase D isoenzymes by alpha- and beta-synucleins. Biochemistry 1998;37:4901-9.

8) Colley WC, Sung TC, Roll R, Jenco J, Hammond SM, Altshuller Y, et al. Phospholipase D2, a distinct phospholipase $\mathrm{D}$ isoform with novel regulatory properties that provokes cytoskeletal reorganization. Curr Biol 1997;7:191-201.

9) Abeliovich A, Schmitz Y, , Fariñas I, Choi-Lundberg D, Ho WH, Castillo PE, et al. Mice lacking alpha-synuclein display functional deficits in the nigrostriatal dopamine system. Neuron 2000;25:239-52.

10) Murphy DD, Rueter SM, Trojanowski JQ, Lee VM. Synucleins are developmentally expressed, and alpha-synuclein regulates the size of the presynaptic vesicular pool in primary hippocampal neurons. J Neurosci 2000;20:3214-20.

11) Ji H, Liu YE, Jia T, Wang M, Liu J, Xiao G, et al.
Identification of a breast cancer-specific gene, BCSG1, by direct differential cDNA sequencing. Cancer Res 1997;57:759 $-64$.

12) Buchman VL, Adu J, Pinõn LG, Ninkina NN, Davies AM. Persyn, a member of the synuclein family, influences neurofilament network integrity. Nat Neurosci 1998;1:101-3.

13) Lavedan C. The synuclein family. Genome Res 1998;8:871 -80 .

14) Duda JE, Shah U, Arnold SE, Lee VM, Trojanowski JQ. The expression of alpha-, beta-, and gamma-synucleins in olfactory mucosa from patients with and without neurodegenerative diseases. Exp Neurol 1999;160:515-22.

15) Zhao W, Liu H, Liu W, Wu Y, Chen W, Jiang B, et al. Abnormal activation of the synuclein-gamma gene in hepatocellular carcinomas by epigenetic alteration. Int J Oncol 2006;28:1081 -8 .

16) Yanagawa N, Tamura G, Honda T, Endoh M, Nishizuka S, Motoyama T. Demethylation of the synuclein gamma gene $\mathrm{CpG}$ island in primary gastric cancers and gastric cancer cell lines. Clin Cancer Res 2004;10:2447-51.

17) Hibi T, Mori T, Fukuma M, Yamazaki K, Hashiguchi A, Yamada T, et al. Synuclein-gamma is closely involved in perineural invasion and distant metastasis in mouse models and is a novel prognostic factor in pancreatic cancer. Clin Cancer Res 2009;15:2864-71.

18) Bruening W, Giasson BI, Klein-Szanto AJ, Lee VM, Trojanowski JQ, Godwin AK. Synucleins are expressed in the majority of breast and ovarian carcinomas and in preneoplastic lesions of the ovary. Cancer 2000;88:2154-63.

19) Jia T, Liu YE, Liu J, Shi YE. Stimulation of breast cancer invasion and metastasis by synuclein gamma. Cancer Res 1999;59:742-7.

20) Roskelley CD, Bissell MJ. The dominance of the microenvironment in breast and ovarian cancer. Semin Cancer Biol 2002;12:97-104.

21) Fidler IJ. Critical factors in the biology of human cancer metastasis: twenty-eighth G.H.A. Clowes memorial award lecture. Cancer Res 1990;50:6130-8.

22) Cauwe B, Van den Steen PE, Opdenakker G. The biochemical, biological, and pathological kaleidoscope of cell surface substrates processed by matrix metalloproteinases. Crit Rev Biochem Mol Biol 2007;42:113-85.

23) Liotta LA, Tryggvason K, Garbisa S, Hart I, Foltz CM, Shafie S. Metastatic potential correlates with enzymatic degradation 
of basement membrane collagen. Nature 1980;284:67-8.

24) Seiki M. The cell surface: the stage for matrix metalloproteinase regulation of migration. Curr Opin Cell Biol 2002;14:624-32.

25) Kawashima M, Suzuki SO, Doh-ura K, Iwaki T. alphaSynuclein is expressed in a variety of brain tumors showing neuronal differentiation. Acta Neuropathol 2000;99:154-60.

26) Fung KM, Rorke LB, Giasson B, Lee VM, Trojanowski JQ. Expression of alpha-, beta-, and gamma-synuclein in glial tumors and medulloblastomas. Acta Neuropathol 2003;106: 167-75.

27) Cairns RA, Khokha R, Hill RP. Molecular mechanisms of tumor invasion and metastasis: an integrated view. Curr $\mathrm{Mol}$ Med 2003;3:659-71.

28) Kim S, Cho SH, Kim KY, Shin KY, Kim HS, Park CH, et al. Alpha-synuclein induces migration of $\mathrm{BV}-2$ microglial cells by up-regulation of CD44 and MT1-MMP. J Neurochem 2009;109:1483-96.

29) Pan ZZ, Bruening W, Godwin AK. Involvement of RHO GTPases and ERK in synuclein-gamma enhanced cancer cell motility. Int J Oncol 2006;29:1201-5.

30) Sjögren K, Liu JL, Blad K, Skrtic S, Vidal O, Wallenius V, et al. Liver-derived insulin-like growth factor I (IGF-I) is the principal source of IGF-I in blood but is not required for postnatal body growth in mice. Proc Natl Acad Sci U S A 1999;96:7088-92.

31) Isaksson OG, Lindahl A, Nilsson A, Isgaard J. Mechanism of the stimulatory effect of growth hormone on longitudinal bone growth. Endocr Rev 1987;8:426-38.

32) Grey A, Chen Q, Xu X, Callon K, Cornish J. Parallel phosphatidylinositol-3 kinase and p42/44 mitogen-activated protein kinase signaling pathways subserve the mitogenic and antiapoptotic actions of insulin-like growth factor I in osteoblastic cells. Endocrinology 2003;144:4886-93.

33) Chan JM, Stampfer MJ, Giovannucci E, Gann PH, Ma J, Wilkinson $\mathrm{P}$, et al. Plasma insulin-like growth factor-I and prostate cancer risk: a prospective study. Science 1998;279: 563-6.

34) Hankinson SE, Willett WC, Colditz GA, Hunter DJ, Michaud DS, Deroo B, et al. Circulating concentrations of insulin-like growth factor-I and risk of breast cancer. Lancet 1998;351: 1393-6.

35) Ma J, Pollak MN, Giovannucci E, Chan JM, Tao Y, Hennekens $\mathrm{CH}$, et al. Prospective study of colorectal cancer risk in men and plasma levels of insulin-like growth factor (IGF)-I and
IGF-binding protein-3. J Natl Cancer Inst 1999;91:620-5.

36) Yu H, Spitz MR, Mistry J, Gu J, Hong WK, Wu X. Plasma levels of insulin-like growth factor-I and lung cancer risk: a case-control analysis. J Natl Cancer Inst 1999;91:151-6.

37) Peyrat JP, Bonneterre J, Hecquet B, Vennin P, Louchez MM, Fournier C, et al. Plasma insulin-like growth factor-1 (IGF-1) concentrations in human breast cancer. Eur J Cancer 1993; 29A:492-7.

38) Reinmuth N, Fan F, Liu W, Parikh AA, Stoeltzing O, Jung YD, et al. Impact of insulin-like growth factor receptor-I function on angiogenesis, growth, and metastasis of colon cancer. Lab Invest 2002;82:1377-89.

39) Dunn SE, Ehrlich M, Sharp NJ, Reiss K, Solomon G, Hawkins $\mathrm{R}$, et al. A dominant negative mutant of the insulin-like growth factor-I receptor inhibits the adhesion, invasion, and metastasis of breast cancer. Cancer Res 1998;58:3353-61.

40) Prager D, Li HL, Asa S, Melmed S. Dominant negative inhibition of tumorigenesis in vivo by human insulin-like growth factor I receptor mutant. Proc Natl Acad Sci U S A 1994;91:2181-5.

41) Li M, Yin Y, Hua H, Sun X, Luo T, Wang J, et al. The reciprocal regulation of gamma-synuclein and IGF-I receptor expression creates a circuit that modulates IGF-I signaling. J Biol Chem 2010;285:30480-8.

42) Ahn KJ, Paik SR, Chung KC, Kim J. Amino acid sequence motifs and mechanistic features of the membrane translocation of alpha-synuclein. J Neurochem 2006;97:265-79.

43) Harmey JH, Bucana CD, Lu W, Byrne AM, McDonnell S, Lynch C, et al. Lipopolysaccharide-induced metastatic growth is associated with increased angiogenesis, vascular permeability and tumor cell invasion. Int J Cancer 2002;101:415-22.

44) Wang JH, Manning BJ, Wu QD, Blankson S, Bouchier-Hayes D, Redmond HP. Endotoxin/lipopolysaccharide activates NFkappa B and enhances tumor cell adhesion and invasion through a beta 1 integrin-dependent mechanism. J Immunol 2003;170:795-804.

45) Xie W, Huang Y, Xie W, Guo A, Wu W. Bacteria peptidoglycan promoted breast cancer cell invasiveness and adhesiveness by targeting toll-like receptor 2 in the cancer cells. PLoS One 2010;5:e10850.

46) Issekutz AC. Removal of gram-negative endotoxin from solutions by affinity chromatography. J Immunol Methods 1983;61:275-81.

47) Munson TE. Guideline for validation of the LAL test as an 
end-product endotoxin test for human and biological drug products. Prog Clin Biol Res 1985;189:211-20.

48) Kim EK, Yun SJ, Ha JM, Kim YW, Jin IH, Yun J, et al. Selective activation of Akt1 by mammalian target of rapamycin complex 2 regulates cancer cell migration, invasion, and metastasis. Oncogene 2011;30:2954-63.

49) Ma QL, Chan P, Yoshii M, Uéda K. Alpha-synuclein aggregation and neurodegenerative diseases. J Alzheimers Dis 2003; 5:139-48.

50) Manivel P, Muthukumaran J, Kannan M, Krishna R. Insight into residues involved in the structure and function of the breast cancer associated protein human gamma synuclein. $\mathrm{J}$ Mol Model 2011;17:251-63.

51) Jiang Y, Liu YE, Lu A, Gupta A, Goldberg ID, Liu J, et al. Stimulation of estrogen receptor signaling by gamma synuclein. Cancer Res 2003;63:3899-903.

52) Jiang Y, Liu YE, Goldberg ID, Shi YE. Gamma synuclein, a novel heat-shock protein-associated chaperone, stimulates ligand-dependent estrogen receptor alpha signaling and mammary tumorigenesis. Cancer Res 2004;64:4539-46. 